\title{
The body as a brand in social media: Analyzing Digital Fitness Influencers as Product Endorsers
}

EL CUERPO COMO MARCA EN INTERNET: ANÁLISIS DE INFLUENCERS DIGITALES FITNESS

COMO PROMOTORES DE PRODUCTO

\author{
Marianny J.B. Silva; Salomão A. Farias; Michelle H. K. Grigg; Maria
}

L. A. Barbosa

* Federal University of Pernambuco; * ${ }^{*}$ Georgia State University; ${ }^{* *}$ Breda University of Applied Sciences; marianny.jbrito@gmail.com; saf@ufpe.br; kovacs.m@ade-buas.nI; lourdesbarbosa@gmail.com

\begin{tabular}{|c|c|}
\hline Historia editorial & $\mathrm{ct}$ \\
\hline Recibido: 29-01-2019 & \multirow{6}{*}{$\begin{array}{l}\text { New social actors have emerged with the social media. Among them, we high- } \\
\text { lighted the digital influencers, people who have millions of online followers, and } \\
\text { induce them in favor or against products and brands to be consumed. Therefore, } \\
\text { we aimed to analyze this endorsement process carried out by digital influencers in } \\
\text { their online profiles, having as research field the fitness market that encourages } \\
\text { people to evaluate and work tirelessly in their bodies. We used the Semiotic Image } \\
\text { Analysis to investigate the postings of three Brazilian digital fitness influencers } \\
\text { and identified four categories that configure the post format: body exposure, body } \\
\text { extension, interaction between influencer and brand/product, and interaction be- } \\
\text { tween influencer and followers. By means of these categories, we identified that } \\
\text { these influencers act as brand avatars, creating an intense link with these prod- } \\
\text { ucts, exposing their bodies in advertisements and extending the meanings of their } \\
\text { good shape to endorsed goods and services. }\end{array}$} \\
\hline Primera revisión: $01-07-2020$ & \\
\hline Aceptado: $30-07-2020$ & \\
\hline Publicado: 25-02-2021 & \\
\hline Keywords & \\
\hline & \\
\hline
\end{tabular}

\section{Resumen}

Palabras clave

Redes sociales; Influencia social; Persuasión
Han surgido nuevos actores sociales con Internet. Entre ellos, destacamos a los influencers digitales, personas que tienen millones de seguidores online, y los influyen a favor o en contra de productos y marcas para ser consumidos. Nos propusimos analizar este proceso de aval que realizan los influencers digitales en sus perfiles online, teniendo como campo de investigación el mercado del fitness que incita a las personas a evaluar y trabajar incansablemente en su cuerpo. Utilizamos el Análisis de imagen semiótica para investigar las publicaciones de tres influencers brasileños e identificamos cuatro categorías que configuran el formato de la publicación: exposición corporal, extensión corporal, interacción entre influencer y marca/producto, e interacción entre influencer y seguidores. Mediante estas categorías, identificamos que estos influencers actúan como avatares de marca, creando un vínculo intenso con productos, exponiendo sus cuerpos en anuncios y extendiendo los significados de su buena forma a bienes y servicios avalados.

Silva, Marianny J. B.; Farias, Salomão A.; Grigg, Michelle H. K. \& Barbosa, Maria L. A. (2021). The body as a brand in social media: Analyzing Digital Fitness Influencers as Product Endorsers. Athenea Digital, 21(1), e2614. https://doi.org/10.5565/rev/athenea.2614

\section{Introduction}

The advancement of technologies in recent years has provided new social, economic and cultural mentalities and behaviors that reflect the lives of individuals in a Digital Age marked by the internet and social media. Thanks to this scenario, the ways of interacting have been extended (Holt, 2016), making it possible for one person to com- 
municate and influence over thousands of other people (Mangold \& Faulds, 2009) in favor or against products and brands to be consumed.

In this constant process of online interaction, individuals become more active, participating in building the perception of others about what companies are and what they offer. Many of these individuals "are gaining a large share of voice in the market" (Booth \& Matic, 2011, p. 184) with their online profiles on Facebook, Instagram, Twitter or YouTube, acquiring millions of followers who are willing to adopt and be engaged daily from posts, being effectively influenced in terms of choices and behaviors. To these users of digital media with thousands of followers is given the name of digital influencers (Araujo et al., 2016; Roth \& Zawadzki, 2018).

Companies already recognize the digital influencers as opinion leaders who mediate the transmission of information, facilitating its dissemination to their online followers (Uzunoglu \& Kip, 2014). Therefore, they are viewed by organizations as potential brand ambassadors who convey messages seen by consumers as more trustworthy and attractive because of their more engaged relationship with them (Lim et al., 2017). In fact, these new celebrities become role models for their followers, being called upon by organizations to show themselves on social networks (Sibilia, 2008), in a constant process of communication that affects brand equity. Despite this, academic researches on social media influencers and on their practical implications are relatively scarce (Godey et al., 2016; Almeida et al., 2018).

Digital influencers represent new possibilities for brand endorsement, bringing different configurations in relation to traditional communication strategies in terms of speed, reach, information flow and engagement. For this reason, in this paper, we aim to analyze the endorsement process of brands and products carried out by digital influencers in their online profiles, having as a research field the fitness market. This market encourages people "to evaluate and work on their bodies in the context of consumer fitness culture - in commercial health clubs and the fitness media, and through personal fitness services" (Maguire, 2008, p. 3). The role of digital influencers in this scenario is to show muscular, good shape, and agile bodies, capable of performing seemingly impossible physical exercises; their bodies are avatars of brand value to communicate products and services (Powers \& Greenwell, 2016) creating an ideal body image by just posting videos and pictures in social media (Belinska, 2018). The exposure of the digital influencers from their bodies guides their followers to adopt the premise 'my body is my temple!', leading them to have a life style based on behaviors and consumptions of different products that will help them perhaps to achieve the ideal shape. Therefore, there is an understanding that the body, with its exposure value, is a commodity (Han, 2012/2018). 
Thus, the basic question underlying this investigation is how the digital fitness influencers endorse products and brands in their online profiles. Does this process follow a structured path? What are the characteristics of the posts? Which ones tend to have a stronger influence on followers? We begin our inquiry with a look at prior research on Social media and the digital influencers and then proceed to a brief discussion of the fitness and the body.

\section{Social media and the digital influencers}

Social Media is defined most simply as "a collection of websites and applications designed to build and enhance online communities for networking and sharing information" (Osborne-Gowey, 2014, p. 55). It is, therefore, a set of network communication platforms that operate thanks to the internet, having as examples Facebook, Twitter, Tumblr, Instagram, YouTube, Bloggers, among others (Meikle, 2016).

These platforms are highly interactive and enable people to communicate, collaborate, and share content, having a global audience with almost immediate response times (Power, 2014). Consequently, social media is perceived as channel of interaction that has convenience, wide availability and low cost for those involved (Uzunoglu \& Kip, 2014; Momany \& Alshboul 2016; Roth \& Zawadzki, 2018). It is a spreadable media that generates more engagement and empowerment of individuals, especially in their role as consumers (Fuchs, 2014/2017). It is precisely through social networks that daily virtual interactions are carried out, giving opportunities for consumers to learn about opinions, skills and lives of others (Vogel et al, 2015).

The sociability on digital platforms has a considerable representation in the projection of the individual, significantly expanding behaviors of social differentiation and reference of the person, modifying patterns of daily life (Castells, 2011). Such network sociability brings possibilities, but also many communication noises generated by excess, by the wide-open and mysterious exposure (Han, 2012/2018).

Using more and more social media, people feel engaged with the brands they use and with other consumers (Hanna et al., 2011), creating relationships and interactions that guide to the consumption of products and the identification with specific enterprises and individuals (Booth \& Matic, 2011). In this scenario of engagement, the digital influencers stand out. They expose their daily lives from social media with photos, videos and texts that show their consumer choices, practices, and opinions, treating intimacy as a spectacle, a show of self (Sibilia, 2008). Through regularly contact with a large audience (Liu et al., 2012), they seem more accessible and closer to people than traditional media artists; they are seen as 'people like us' and 'friends' of their 
followers (Meyers, 2017), provoking and inspiring people, being a reference for them. This proximity, however, does not extract the celebrity status of influencers, but reinforces the idea that anyone can be famous by winning a more or less comprehensive showcase (Sibilia, 2010).

For this reason, these influencers receive offers from companies to advertise goods and services in their posts (Almeida et al., 2018). They are sponsored to indicate brands and products, crediting the quality and benefits of these in a spontaneous and natural way (Centeno \& Wang, 2017; Jin \& Phua, 2014). Thereby, their audience are more likely to follow their recommendations by understanding that the proclaimed message is more trustworthy and attractive (Lim et al., 2017). At the same time, digital influencers offer their images to the endorsed product, transferring, extending their characteristics, identities and meanings to that advertised good or service (Belk, 1988, 2014).

When such a message is exposed through photographs and filming, the endorsement of the brand is also made from the appearance, having in the body its main source of signification. The role of the corporeal and the lifestyle it imposes are topics discussed in the following section.

\section{The fitness and the body}

The body is understood as a spectacle that carries meanings in the contemporary world, being described as an individual and collective place (Goellner, 2008), involved in social and cultural dimensions that justify the efforts of consumers in favor of their improvement, considering that:

Our bodies are sources of concern. Proclamations from health experts and our experience of stress, aging, and disease raise concerns about how well and for how long - our bodies work. At the same time, daily interactions with others and with media images remind us that we are judged based on our bodily appearances and performances. (Maguire, 2002, p. 449)

Individuals reveal characteristics of identity, tastes, processes of choice and aspirations through their bodies. The subject's own perception, experience and feeling are given through the body that serves as a mediator of the individual's internal and external domain. It is precisely a molded, co-constructed body that receives marks from other bodies, contributing to the establishment among individuals of durable dispositions, reinforcing the process of bodily adjustment imposed by society (Fontanille, 2019). 
Thus, the search for a body that meets social and media demands for appearance and performance has boosted the development of the fitness lifestyle. It is characterized by exercises, many of them bodybuilding taken to the extreme; diets and even cosmetic surgeries (Crossley, 2005). In the daily life of the consumer who adopts such a way of life, the body is understood as a source of identification and subjectivation, directing behaviors and sociability that reinforce the uniformity of the bodies through a muscular referential or good shape (Bisma et al., 2017; Sueitti \& Sueitti, 2015), involving a move away from obesity and the promotion of an active lifestyle supplemented by vigorous exercises (Albinsson et al., 2017).

The fitness style is a reflect of contextual norms about an idealized body, producing stigmas for those whose corporeal element is not considered acceptable (Wedow et al., 2017), inducing of body exposure that must reflect beauty, health, sensuality and success that standardize gestures and practices (Goellner, 2008), being treated as a commodity (Han, 2012/2018). In consequence it is necessary to expose the body, communicating self-care, effectiveness in bodybuilding practices, "dedication, evangelism and self-transformation" (Powers \& Greenwell, 2016, p. 529). Fitness practices involve a sharp discipline can generate pain and abdication, but also happiness and transformation that create a life narrative (Scott et al., 2017). Social networks are important tools to disseminate these narratives, making it possible to expose the body through video and photo posts (Belinska, 2018).

\section{Method}

The postings of digital fitness influencers who act as brand endorsers are investigated in this study, with the objective to analyze this virtual endorsement process. Among the existing social networks, it was opted to analyze the postings on Instagram.

The social networking website Instagram consists of profiles which users and brands use to post photos or videos with short descriptions and often at least one hashtag (a key word relating to the contents of the message, preceded by the symbol \#). Users can also make use of built-in filters to edit a photo before they publish it. (Roth \& Zawadzki, 2018, p. 103)

This platform focuses especially on the visual appeal from the photographs and on the number of followers that each profile has, being especially efficient in the B2C communication (Roth \& Zawadzki, 2018). In addition, its popularity has grown in recent years. According to Hannah Kuchler (2017), Instagram is adding 100 million users and 1 million advertisers every four months. It also enables integration with other social networks by sharing user posts to other platforms such as Facebook, Twitter, 


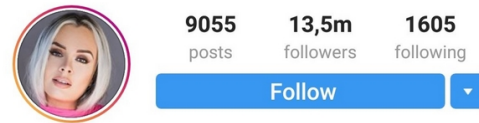

Juliana Salimeni

Public Figure

TV hostess/ fitness Model

* CONTATO: rodrigo@mim.digital

VÍDEO NOVO NO CANAL 2

SEE TRANSLATION

www.youtube.com/watch?v=RkoK9NMyAn8

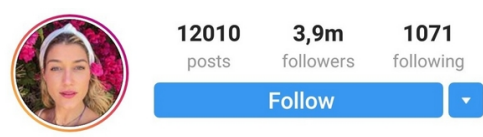

Gabriela *

Public Figure

B̈razilian * Welcome to my life

๑ contato@mapbrasil.ag @

contato@gabrielapugliesi.com

首@vendimeusofa|

caixa postal:79938 cep-04544-970

youtu.be/K_SqaOWBHcc
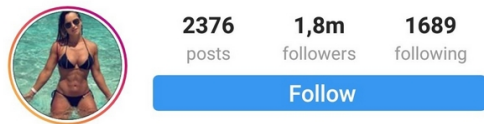

Alice Matos

Public Figure

Businesswoman, athlete, journalist

owner @labellamafia group

Caixa Postal 8010, CEP:88015-973

• alicematos@labellamafia.com.br

bit.ly/tvLBM

Miami. Florida

Figure 1. Instagram Profiles of Digital Fitness Influencers

Source: Salimeni (n.d.), Pugliesi (n.d.), Matos (n.d.)

Tumblr and Flickr. Instagram allows users to like and comment posts as well, making these actions indicators of communication efficiency, of the degree of interaction that the user profile has and of their popularity.

A specific profile of digital influencer was selected, adhering following criteria: a) has a fitness lifestyle, b) has more than 1 million of followers on Instagram, and c) advertises goods and services on his/her profile. In addition to these criteria, it was sought to analyze influencers who had the same nationality and gender, in order to observe possible similarities in the endorsed products, in the forms of communication and in the public that follows the influencer. Thus, three Brazilian ${ }^{1}$ female digital influencers considered fitness models or muses were selected for this qualitative research, they are: Juliana Salimeni, Gabriela Pugliesi and Alice Matos (See figure 1).

These influencers meet the criteria demanded by the research. In addition, they have considerable differences in terms of number of followers. Such a difference can be important in the development of the communication strategies that the influencers adopt and in the attractiveness of them to the companies. This diversity contributes to an in-depth analysis of the forms of postings and the online interaction generated by profiles with more than a million followers.

The posts made by Juliana, Gabriela and Alice during a month (October 1st to November 1st, 2018) that involved the announcement of brands and products were analyzed using the Semiotic image analysis that aims to identify the system of signs involved in the image and its description in order to find out how they produce meaning (Penn, 2000). Following the guidelines described by Gemma Penn (2000), a dissection of the image followed by its articulation or reconstruction was performed. The steps were identification and cataloging of material elements (denotative inventory) and analysis of higher significance levels, starting with a

\footnotetext{
The choice for Brazil reflects the growth of the fitness market in the country. According to the IHRSA (International Health, Racquet \& Sportsclub Association) Global Report published in 2017, Brazil is the second country with the largest number of gyms in the world, reaching a total of 34,509 establishments, and ranks fourth in the world ranking with 9.6 million consumers of this type of service, reflecting a concern of the Brazilian population to take care of the appearance, generating demand in the segments of beauty and fitness in particular (IHRSA, 2017).
} 
connotative understanding of what was described in the previous phase. At the end, a mental map was developed for each influencer using the Xmind 8 software to summarize the connotative aspects shown in her images and texts on Instagram. The authors acted as validation judges of all the analysis process, arguing and adjusting the results of this step. It was collected a total of 63 posts with images and texts that endorsed specifics products/brands (See table 1).

\begin{tabular}{lccc}
\hline \multicolumn{1}{c}{ Influencer } & $\begin{array}{c}\text { Collected } \\
\text { posts }\end{array}$ & $\begin{array}{c}\text { Collection pe- } \\
\text { riod of posts* }\end{array}$ & $\begin{array}{c}\text { Brands an- } \\
\text { nounced }^{* *}\end{array}$ \\
\hline Juliana Salimeni & 24 & $01 / 12 / 18$ & 20 \\
Gabriela Pugliesi & 23 & $02 / 12 / 18$ & 19 \\
Alice Matos & 16 & $03 / 12 / 18$ & 13 \\
TOTAL & 63 & & 52 \\
\hline
\end{tabular}

* Instagram (version for android and IOS) stopped showing the number of likes in photos in Brazil since 2019. However, until now, in the web version of Instagram it is still possible to access the posts and view the number of likes.

${ }^{* *}$ from October 1st to November 1st, 2018

Table 1. Characteristics of posts selected for semiotic image analysis

Such technique made possible the analysis and discussion of collected data presented in the following section.

\section{Analysis and Discussion}

In this section are the findings of the research, divided into: Characteristics of endorsed brands and products, and Analysis of Posts. A subsection was also developed with the main findings of the research, and the mental map of the posts.

\section{Characteristics of endorsed brands and products}

During the period of one month the analyzed influencers posted images and texts that endorsed brands and products from different segments. In total, 52 companies were announced through the demonstration of their product, its use and its description made by the digital influencer. Juliana Salimeni endorsed 20 brands in the 24 posts made, highlighting 8 times the women's clothing company 'Chocolate Doce'. In turn, Gabriela Pugliesi announced 19 brands in her 23 posts, emphasizing 4 times the company 'Body for sure' specialized in fitness style clothing and beachwear. Lastly, Alice Matos endorsed 13 organizations in the 16 posts she made, citing the brand of sportwear 'Labellamafia' 6 times. Therefore, among the digital influencers, Juliana 
stands out for having more posts and endorsing more brands than the others. This element reflects the organizations' interest in having their names and products displayed on the Instagram profile followed daily by more than 13 million people, facilitating the dissemination of information about the product (Uzunoglu \& Kip, 2014) and the desire of possess it with the aid of the image of its endorser.

From the endorsements made by the digital influencers, 13 initial categories of announced products were established. These categories were grouped into 5 broad categories, showing the segments of promoted goods and services (See table 2).

\begin{tabular}{|c|c|c|c|c|}
\hline $\mathrm{N}^{\circ}$ & Broad Category & Early Category & Total of & ments \\
\hline \multirow{5}{*}{1} & \multirow{5}{*}{ Clothing } & Fit Clothing & 11 & \multirow{5}{*}{32} \\
\hline & & Casual Clothing & 12 & \\
\hline & & Accessories & 2 & \\
\hline & & Footwear & 2 & \\
\hline & & Underwear and Beachwear & 5 & \\
\hline \multirow{2}{*}{2} & \multirow{2}{*}{ Food } & Food supplements & 6 & \multirow{2}{*}{22} \\
\hline & & Healthy, fit or natural food & 16 & \\
\hline \multirow{2}{*}{3} & \multirow{2}{*}{$\begin{array}{l}\text { Aesthetics and } \\
\text { Cosmetics }\end{array}$} & Bodybuilding services & 2 & \multirow{2}{*}{11} \\
\hline & & Aesthetic Products & 9 & \\
\hline \multirow{2}{*}{4} & \multirow{2}{*}{ Travel } & Hospitality & 3 & \multirow{2}{*}{6} \\
\hline & & Transportation Services & 3 & \\
\hline \multirow{2}{*}{5} & \multirow{2}{*}{ Communication } & Beauty and Fitness Events & 8 & \multirow{2}{*}{11} \\
\hline & & Communication media and service & 3 & \\
\hline
\end{tabular}

Table 2. Products categories

Clothing was the category most endorsed by the digital fitness influencers (32 announcements $-39 \%$ ). It is formed by products that dress and ornament the body, involving clothes suitable for the practice of exercises (clothes fit), casual clothes, footwear, underwear and beachwear, and accessories such as earrings and glasses. The second most advertised category was food (22-26,8\%), represented by supplements and healthy, natural and/or organic foods, without sugar, gluten, fat, oil and lactose. The aesthetic and cosmetic (11) and communication (11) categories represented each 13,4\% of the posts, in which the first category groups bodybuilding activities (personal trainers services) and body care from the use of goods and services aimed at the beauty market, such as hair products, beauty clinics, beauty salons, costume designer, makeup artist and manicurist. In turn, the category of communication is comprised of activities for the dissemination of fitness and beauty fairs and events, media such as magazines and TV channels, and communication services such as marketing agencies. 
Finally, the travel category encompasses facilities and transportation services such as hotel accommodations, airfare and luxury car rentals (6-7,3\%).

Thus, all the brands and products announced by the digital influencers communicate from the endorser elements linked to the care of the body, the cult to the beauty of the form and the shape, and the status generated from it (Crossley, 2005; Maguire, 2002; Powers \& Greenwell, 2016). Thereby, the endorsed products in the posts help in the exposure of the fitness lifestyle, reflecting from the body the beauty, health, sensuality and success (Goellner, 2008) of these digital influencers.

\section{Analysis of Posts}

The postings made by digital influencers involved photographs, texts, emojis, and hashtags. All these elements were considered for the Semiotic Analysis of the image to be performed. In a spreadsheet, the denotative and connotative inventories of each influencer were developed, highlighting in bold the main themes and characteristics that gave rise to categories in a mental map. In the table 3, it is showed how the denotative and connotative descriptions were made.

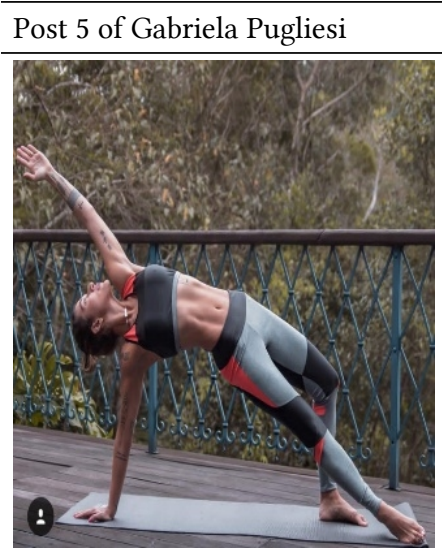

Text: The silence and the contact with nature increasingly refine our attunement to the universe. We perceive our insignificance in the face of the greatness of life! Good morning (emoji of the hands together- prayer) (emoji of the plant in the earth) @bodyforsure

(Pugliesi, 2018a, own translation)

\section{Date: $08 / 10 / 2018$}

Denotative aspect of image: Young, lean female figure in a yoga position, looks concentrated. Right hand is resting on the floor covered by a small rug, holding the body upright, raised hips, left leg slightly bent to the floor, and right leg extended, with right foot touching the floor with the rug. The left arm is lifted upward and the woman's face follows the direction of that arm (as if looking up at the sky). Hair caught, and tattoos left arm. Tight top and workout pants in light gray, dark, black and orange coloring the slender body of the woman. The setting is apparently a wooden bridge, with "railing" in blue metal arabesques and in the background a greyish forest.

Denotative aspect of text: Greeting followers through the good morning, use emojis and quote the brand of clothing she is using in this photo.

Connotative aspect: Body in motion, attunement, yoga - Connection with nature, universe and with all living beings. Motivational phrase linked to the meaning of life - connection between beings, peace expressed by silence and concentration. Body as an extension of the connection with nature. Hand on the ground - approach with nature. Idea of Mother Earth - Indian culture - PachaMama. Essence of being is nature, the earth, which implies sustenance, fertility. Clothing appropriate to the occasion, it is an extension of the purpose of the activity. Clothing as second skin and tattoos as an expression of bodily freedom.

Table 3. Example of denotative and connotative inventory for each post 


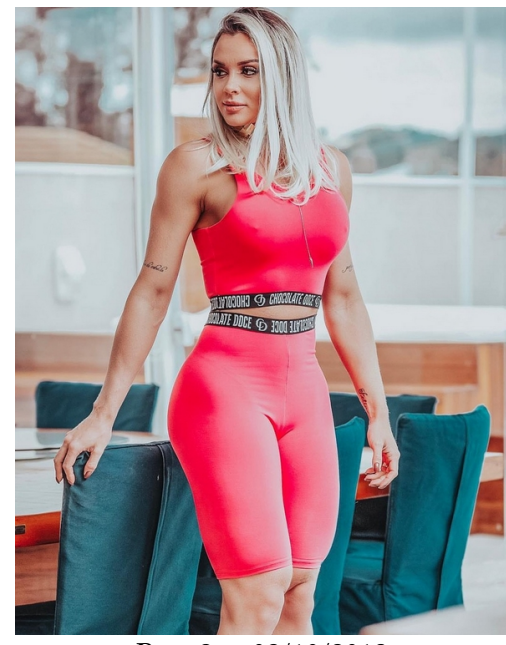

Post $2-02 / 10 / 2018$

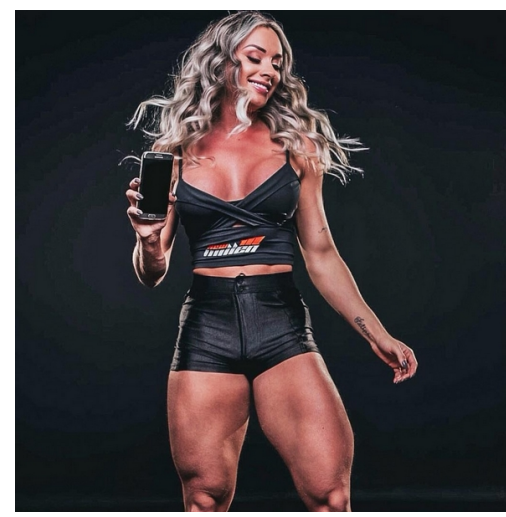

Post $6-05 / 10 / 2018$

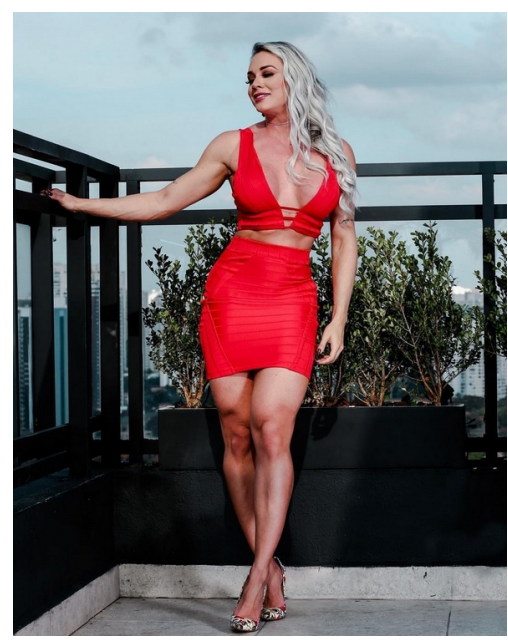

Post $13-19 / 10 / 2018$

* From top to bottom: clothing advertisement photo; food supplements advertisement photo; and clothing advertisement photo.

Figure 2. Muscular body of Juliana Salimeni

Source: Salimeni (2018a, 2018b, 2018c)
Through this analyze process, we have identified four general categories in the practice of product endorsement conducted by digital fitness influencers in their profiles on Instagram; they are: body exposure, body extension, interaction with followers, and interaction with products/ brands. These categories are described in the following sections from each analyzed digital fitness influencer.

\section{Juliana Salimeni}

Most of photographs posted by Juliana highlighted her muscular body, the care with it, and her status of fitness muse through endorsed products (See figure 2).

Her body exposure reaffirms the fitness lifestyle adopted by Juliana (Sueitti \& Sueitti, 2015; Bisma et al., 2017). Such online exposition enables a narrative of life (Scott, Cayla \& Cova, 2017) that communicates the effort for a bodily self-transformation (Powers \& Greenwell, 2016, p. 529). Her muscle body can be described as an hourglass shape, (shoulders and hips on the same line and thin waist) which is understood as an ideal representation of the sensuous female body. This sensuality is also reflected in the clothes endorsed by Juliana. They are just and shape the body, serving as second skin, getting it exposed from the duality between the naturism of the semi-naked body and the efforts for its modeling; between the innate versus the acquired body.

Juliana's exposed body also reflects her sensuality through her hair (See figure 3, post 11). The long hair adopted by this influencer is associated with eroticism and femininity, thanks to the description given by Roman mythology to the goddess of love Venus, a female figure with long hair. In addition, the color of Juliana's hair is described in posts as platinum, an expensive and precious metal. Therefore, this color symbolizes power, luxury, wealth and distinction. The exposed body also communicates freedom, either by the tattoos that Juju Salimeni possesses, among them that of a diamond in the arm (power, 
wealth, and distinction) (See figure 3, post 17), and by the posts in which the body is shown in movement. This bodily freedom reflects the innumerable possibilities in rebuilding the corporeal, having in the body the main source of efforts (Maguire, 2002), making it a permanent sketch.

Beyond to exposure, the body and its meanings have been extended to products used and endorsed by the digital influencer (Belk, 1988, 2014). The wealth and the distinction are extended from the rents of luxury cars and the golden jewelry and accessories used by Juliana that refer (or are) to gold, metal associated with power, high status and magnificence (See figure 3, post 10). Already the sensuality is extended by the use of high heels and dark glasses, besides the clothes. Finally, in a cause and effect relationship, the exposed body is extended by body care through the following products: vitamins and food supplements for muscles, fit foods (See figure 3, post 10), aesthetic procedures and sneakers appropriate for bodybuilding.

In addition to the exposed body and its extended meanings for endorsed products, the posts reveal the interaction between the influencer and the brand/good/service and between the influencer and his followers. In the first theme, three elements were observed: i) the product exposure - the photographs posted by the fitness influencer were of the product being shown (See figure 4, post 9) or used by her (See figure 4, post 23) or the image of the products without Juliana's appearance (See figure 4, post 22).

The post 22 was even the only one which contained a photograph without the presence of the influencer in it. It was also the post that got the fewest likes (7.695) and comments (132) among the 24 published by Juliana on Instagram. This finding indicates that the efficiency of endorsement in terms of interaction is best achieved through postings that bring the image of the digital influencer because she acts as an avatar of brand value (Powers \& Greenwell, 2016) and is the main source of interest of followers. ii)

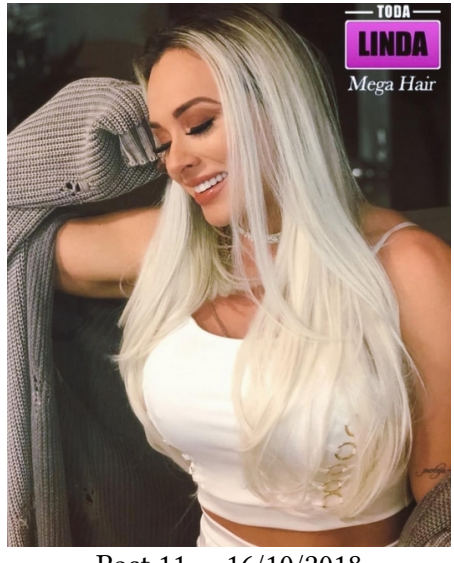

Post $11-16 / 10 / 2018$

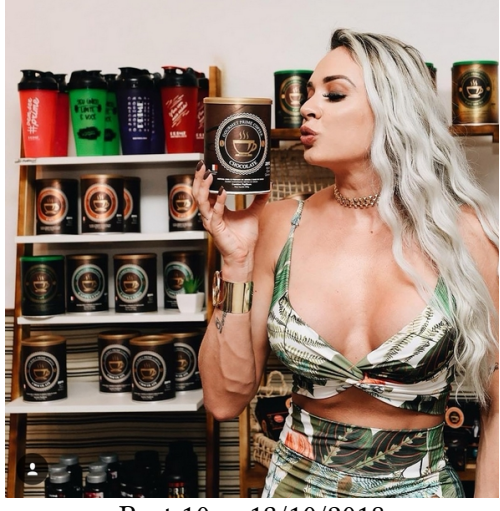

Post $10-13 / 10 / 2018$

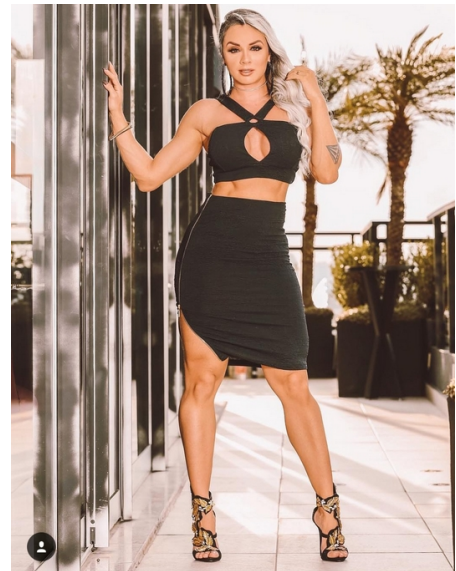

Post $17-26 / 10 / 2018$

* From top to bottom: Mega-hair advertisement photo; Gold accessories and advertisement of coffee/chocolate/cappuccino without sugar, gluten and fat photo; and High heel and diamond tattoo on the arm - Clothing advertisement photo.

Figure 3. Body exposure and Body Extension - Juliana Salimeni

Source: Salimeni (2018d, 2018e, 2018f) 


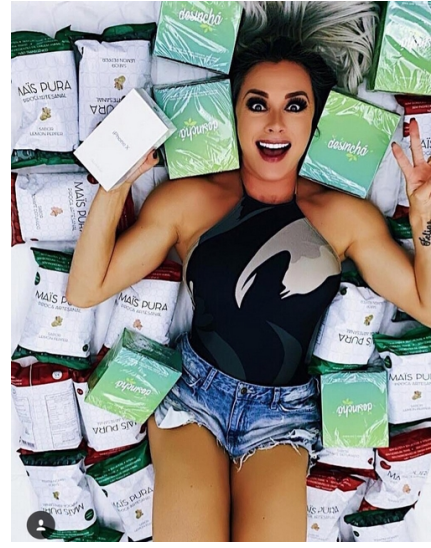

Post $9-11 / 10 / 2018$

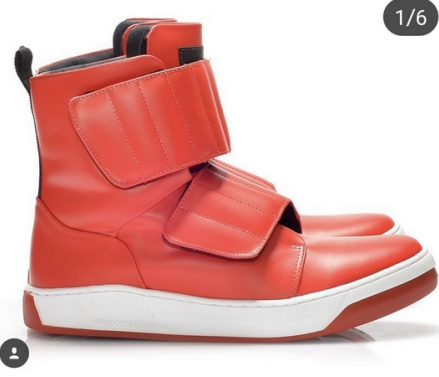

Post $22-30 / 10 / 2018$

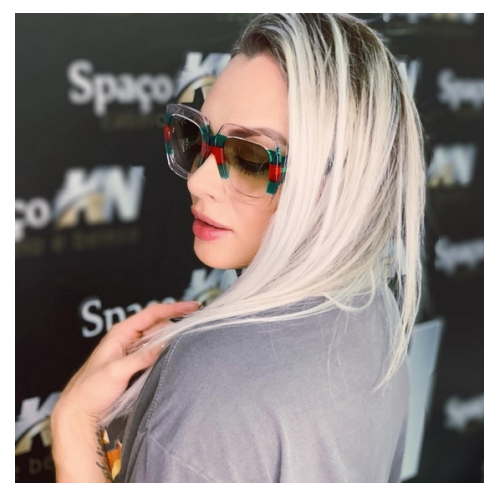

Post $23-31 / 10 / 2018$

* From left to right: Fit food advertisement photo; Tennis advertisement photo; and Sunglasses advertisement photo.

Figure 4. Products exposure - Juliana Salimeni

Source: Salimeni (2018g, 2018h, 2018i)

The relationship with companies - in addition to endorsing the brands, Juliana also owns two brands that she advertises (an esthetic clinic and a women's clothing company) and is a business partner of at least one other. All of them were cited by Juliana in the post text, being described throughout the sentence or just mentioned with the use of the hashtag; and iii) emotions she expressed about the products - some parts of the messages revealed Juliana's avowed feelings about them (See table 4).

\begin{tabular}{ll}
\hline Emotion & Text \\
\hline Affection/love & $\begin{array}{l}\text { Post 11: (mega hair advertisement) What perfection are the luxury mega hairs of @to- } \\
\text { dalindamegahairoficial!! I love it because they are super practical and you can take it and } \\
\text { put it on your own, anywhere !! (Salimeni, 2018d, own translation) }\end{array}$ \\
\hline Desire & $\begin{array}{l}\text { Post 15: (dress advertisement) [...] I just did not want to take it anymore (emoji cackling } \\
\text { with tears) and you're still going to see me repeat a looooooot!! (two emoji of two pink } \\
\text { hearts) (Salimeni, 2018j, own translation) }\end{array}$ \\
\hline Dependency & $\begin{array}{l}\text { Post 12: (peanut paste advertisement) [...] That I do not live without, it is love affair } \\
\text { (emoji with red heart) \#mandubim \#proveaddiction (Salimeni, 2018k, own translation) }\end{array}$ \\
\hline \multirow{3}{*}{ Happiness/Proud } & $\begin{array}{l}\text { Post 4: (Car rental advertising) Our days in Orlando were even cooler because we had the } \\
\text { support of @floridarentalcar who booked a huge and super stylish car for our whole } \\
\text { guys!! (Salimeni, 2018l, own translation) } \\
\text { Post 14: (Fitness fair advertisement) We are very proud to be ambassadors of this fair that } \\
\text { has already become a reference in the fitness world !! (Salimeni, 2018m, own translation) }\end{array}$ \\
\hline
\end{tabular}

Table 4. Emotions Juliana Salimeni expressed about the products

The emotions described by this digital influencer were all positive and communicate to the followers that she does not endorse the products only, but also uses them in her daily live, acquiring appreciation for them, leading to feelings of affection, love, desire, happiness, pride and even dependence. Such elements of influencer proximity 
with the brand/product can make followers see the message as more trustworthy and attractive (Lim et al., 2017).

As for the interaction between influencer and followers, Juliana Salimeni communicated with them in a spontaneous and natural way (Jin \& Phua, 2014; Centeno \& Wang, 2017) through six types of messages: motivational Phrases, questions, prize draw, promotional codes, instructions and invitations (See table 5).

\begin{tabular}{|c|c|}
\hline $\begin{array}{l}\text { Types of } \\
\text { interaction }\end{array}$ & Text \\
\hline \multirow[b]{2}{*}{$\begin{array}{l}\text { Motivational } \\
\text { Phrases }\end{array}$} & $\begin{array}{l}\text { Beauty- Post 1: (modeling belt advertisement) [...] I'm totally in favor of everything that can } \\
\text { help us feel more beautiful!! (Salimeni, 2018n, own translation) }\end{array}$ \\
\hline & $\begin{array}{l}\text { Determination: Post 17: (dress advertisement) The beautiful is to see you fight, believe, nothing } \\
\text { shakes a brave heart. The beautiful thing is to see you resist. See you against logic. No dark } \\
\text { scares a soul full of hope. (Salimeni, 2018f, own translation) }\end{array}$ \\
\hline Questions & Post 2: (Clothing advertisement) Is it cute girls? (Salimeni, 2018a, own translation) \\
\hline Prize draw & Post 9: (Fit food advertisement) DRAW REALIZED!! (Salimeni, 2018g, own translation) \\
\hline $\begin{array}{l}\text { Promotional } \\
\text { codes }\end{array}$ & $\begin{array}{l}\text { Post 5: (Food Supplement advertisement) [...] Use my JUJU10 coupon of discount at www.ofi- } \\
\text { cialfarma.com.br (emoji of arm tensioning the biceps) (Salimeni, 2018o, own translation) }\end{array}$ \\
\hline \multirow{3}{*}{ Instructions } & $\begin{array}{l}\text { Product features - Post 10: (Fit food advertisement) [...] The whole functional line of coffee, } \\
\text { chocolate and cappuccino is zero sugar, zero gluten and zero fat (Salimeni, 2018e, own transla- } \\
\text { tion) }\end{array}$ \\
\hline & $\begin{array}{l}\text { Product benefits - Post 16: (Food Supplement advertisement) This product is already the dar- } \\
\text { ling of athletes and fitness guys because they FIGHT EFFECTIVELY THE LOCATED FAT! (Sal- } \\
\text { imeni, 2018f, own translation) }\end{array}$ \\
\hline & $\begin{array}{l}\text { Where to find the products - Post 22: (sneakers advertisement) They are all for sale in the } \\
\text { physical store of @ @hardcorefootwear or by the site www.hardcorefootwear.com.br (sky emoji } \\
\text { with three stars) (emoji of gray sneakers) (Salimeni, 2018h, own translation) }\end{array}$ \\
\hline Invitations & $\begin{array}{l}\text { Post 13: (Fitness Fair and clothing advertisement) I'll be there at the booth of @chocolatedoce- } \\
\text { oficial using the most beautiful looks we prepared for you! I'll wait for you there, huh ?? (Sali- } \\
\text { meni, 2018c, own translation) }\end{array}$ \\
\hline
\end{tabular}

Table 5. Types of interaction - Juliana Salimeni

The motivational phrases aimed to encourage followers to make them determined for their purposes, including to achieve the desired beauty through any good, service and behavior that leads to this intended purpose. The questions and invitations apparently aimed to lead the followers to interact through the comments, establishing a dialogue from the post, aiming to generate greater engagement (Fuchs, 2014/2017). Thus, the instructions were intended to clarify potential followers' questions about the features and benefits of the endorsed products, as well as their points of sale, mediating the transmission of information between company and consumer (Uzunoglu \& Kip, 2014). Lastly, the prize draw and the promotional codes aimed to offer some advantage, some benefit to the followers. Therefore, the posting of the prize draw (post 9) was the most liked (232.344) and most commented (95.964) among the posts made by 


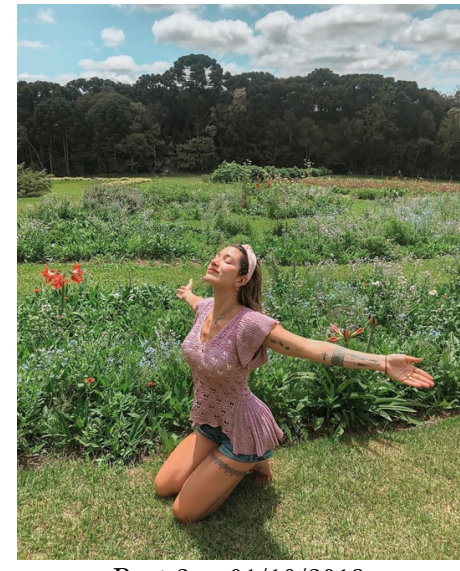

Post $2-01 / 10 / 2018$

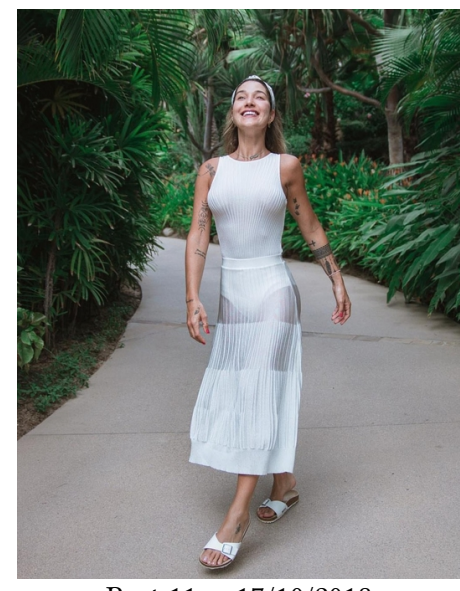

Post $11-17 / 10 / 2018$

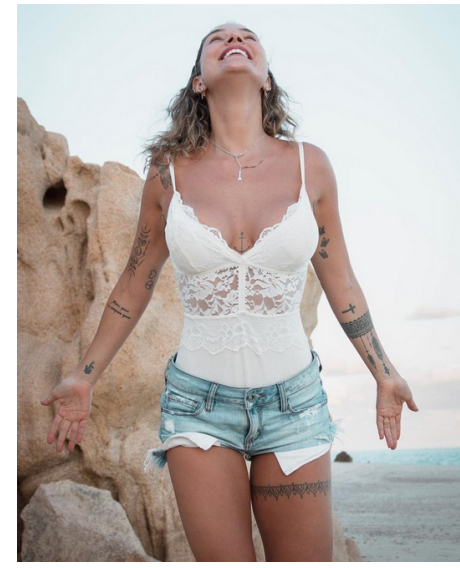

Post $13-19 / 10 / 2018$

* From top to bottom: Clothing advertisement photo; Clothing advertisement photo; and underwear advertisement photo.

Figure 5. The body and the nature Gabriela Pugliesi

Source: Pugliesi (2018b, 2018c, 2018d)
Juliana, appearing as strategy that reached the greatest interaction of the audience.

\section{Gabriela Pugliesi}

Most of photos highlighted her connection with nature, her body as part of the environment and the tuning of these ideals with the endorsed products (See figure 5).

Gabriela's body exposed in the posts is, therefore, a form of connection with the nature, highlighting the idea of Mother Earth represented in the indigenous culture as PachaMama, divinity related to a female figure who creates, who produces everything, showing the need for the bodily and identity connection with the nature that purifies and binds the humans to their origins. As a reflection of this world view, her body is slim and lean, reflecting the spirituality and balance sought from practices, such as Pilates and yoga. Consequently, the muscles are not so apparent, because the central main of this influencer is to expose a philosophy of life that generates health and a good shape (Maguire, 2008; Bisma et al., 2017).

The clothes used by Gabriela represent a second skin, modeling and exposing the body, but offering mobility, comfort and convenience for the activities performed. These products are extensions of the purposes of the activity itself, linked to the freedom of the body in motion, an agile body as a result of an active lifestyle (Albinsson et al., 2017; Powers \& Greenwell, 2016). At the same time, the clothes reveal the semi-naked body, sign of the adopted naturism, showing the youth, reaffirming the idea of fertility and femininity and freedom through tattoos. The clothes highlight the sensuality of the body too (See figure 5 , post 13) and reaffirm the connection with the natural from the process of making the hand, as in the knitwear endorsed by Gabriela (See figure 5, posts 2 and 11). As soon, the body exposure of this digital fitness influencer is based on freedom, connection with nature and less muscular body format. 
The meanings of the exposed body are transferred and exported to the products advertised by the digital influencer (Belk, 1988, 2014). As already mentioned, some clothes are made with natural raw materials which externalize the connective aspect with nature and the quest for comfort in dress. In particular, six posts by Gabriela bring photographs of her in bikinis, revealing her body and her connection to the beach, with the sea as a ritual of cleansing and bodily and mental purification (See figure 6, post 7). Along with this, is added the announcement of resorts that make this contact with nature.

She also reveals the care to the body from the endorsement of certain categories of goods and services. Fit food is associated with the natural foods that quench the body and the soul, which purify the being through food as a ritual (See figure 6, post 15) in a process of sharing and communion. This communion is also extended from the collective practice of physical exercise and practice of Yoga (See figure 6, post 21) that refer to the idea of bodily freedom, movement, comfort and meditation, linked to the balance between body and spirit. Thus, the products endorsed by Gabriela help in the adoption and maintenance of a philosophy experienced by the influencer that transforms body and mind and guides her online narratives (Scott et al., 2017).

The postings also point to an interaction between influencer and brand/product composed by three elements: i) the product exposure - the photographs published by Gabriela were of the product being shown (See figure 7, post 18) or used by her (See figure 7, post 9) or the image of the good/service with the influencer and other people (See figure 7, post 14).

Posts with photographs showing the influencer using the product generated the greatest interactions with the public, demonstrating that this exposure strategy is the most efficient in terms of audience engagement. Post 9, for example, had the highest number of likes $(127,536)$ and

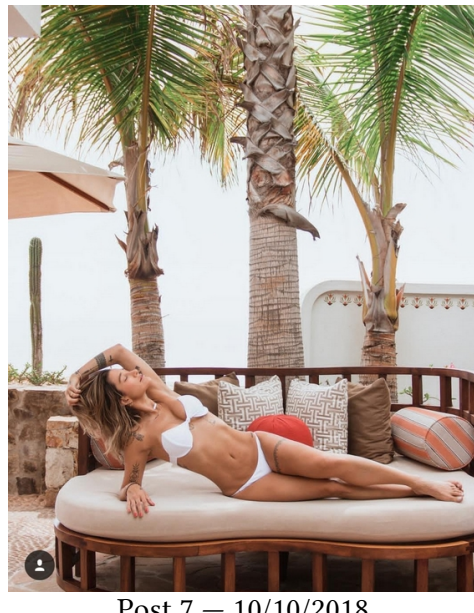

Post $7-10 / 10 / 2018$
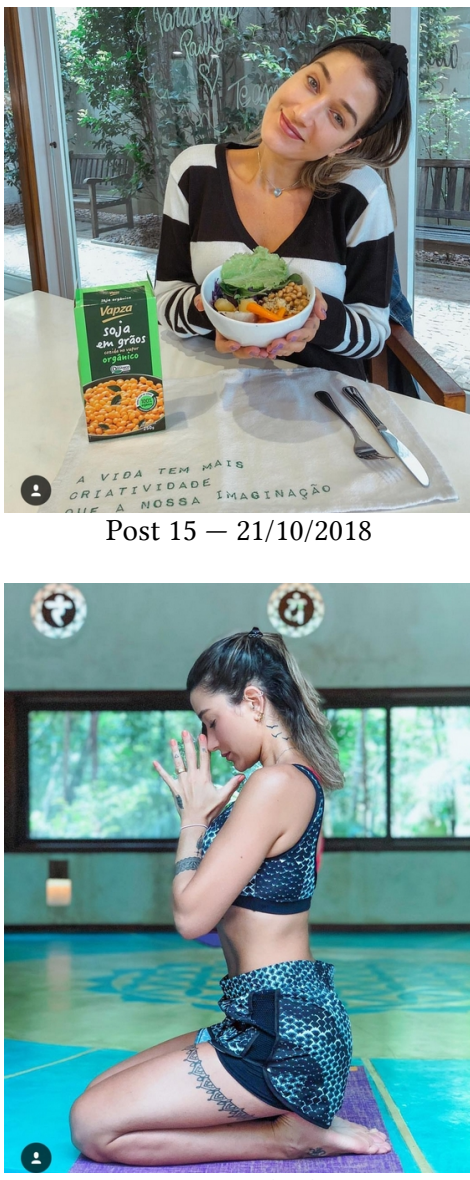

Post $21-29 / 10 / 2018$

* From top to bottom: Hotel resort and bikini advertisement photo; Fit food advertisement photo; and Yoga Clothing advertisement photo.

Figure 6. Body Extension - Gabriela Pugliesi

Source: Pugliesi (2018e, 2018f, 2018g) 


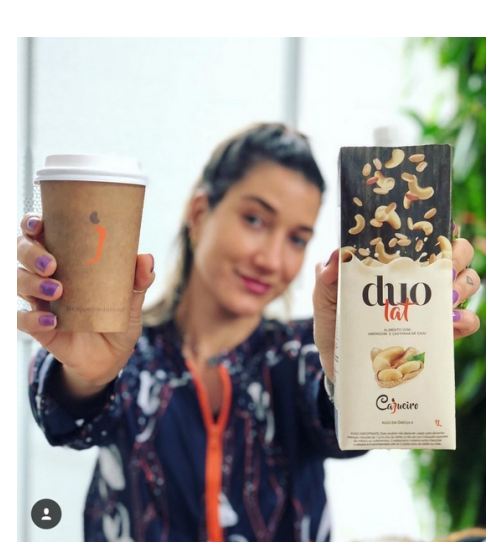

Post $18-22 / 10 / 2018$

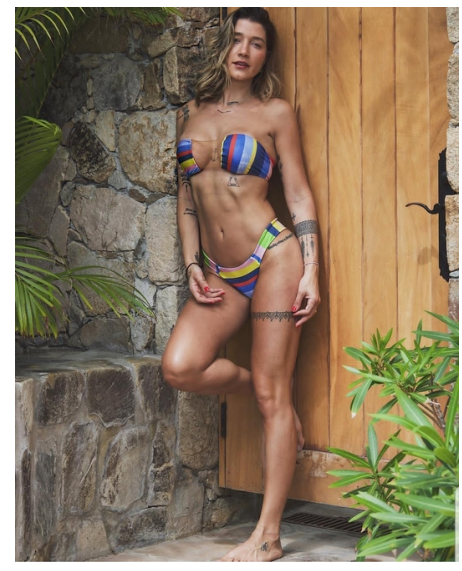

Post $9-15 / 10 / 2018$

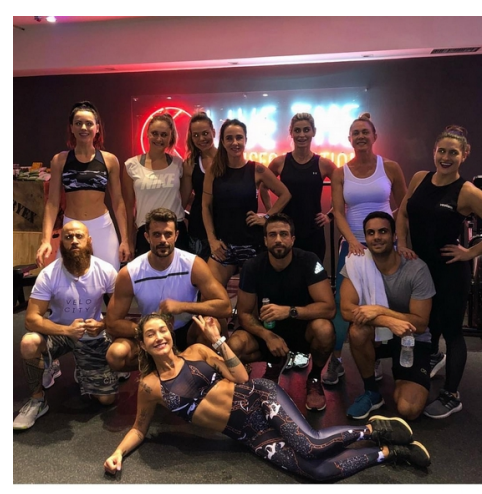

Post $14-20 / 10 / 2018$

* From left to right: Vegetal drink advertisement photo; Bikini advertisement photo; and Physical Fitness Center advertisement photo.

Figure 7. Products exposure - Gabriela Pugliesi

Source: Pugliesi (2018h, 2018i, 2018j)

comments (834) among the analyzed posts by bringing an endorsement to the bikini Gabriela used in photography. It can also be considered that in bringing this image with a good part of the body of the exposed influencer, the post drew more attention from the followers, demonstrating the importance of exposing the body for the most efficient process of attraction and communication in the profiles of digital fitness influencers, corroborating with Jennifer Maguire's (2002) premise that the appearance and performance corporal are means of attraction, judgments and stigma.

The post 18 in which the product is only shown by the influencer received the least number of likes $(6,911)$ and the post 14 , that presents a photograph of a fitness center service, received the smallest amount of comments (30). For the first, the low interaction may have been due to the role of influencer in the ad; she appears discreetly, emphasizing the product; the second reveals a somewhat confused photograph with many people and therefore a lot of visual information, which can generate discomfort in the understanding of the message communicated. These two elements contribute to the understanding that the endorser should be featured in the posted photograph, acting as the unique avatar of the product advertised (Powers \& Greenwell, 2016). ii) relationship with companies - Gabriela acts only as endorser of the brands and products disclosed, citing them in her texts through phrases, markings and hashtags, and iii) the emotions - this influencer expressed in her text posts some emotions about the endorsed products (See table 6). 


\begin{tabular}{ll}
\hline Emotion & Text \\
\hline \multirow{2}{*}{ Affection/love } & $\begin{array}{l}\text { Post 12: (fitness clothing advertisement) When @bodyforsure is gym look and day too! I love } \\
\text { it! (Pugliesi, 2018k, own translation) } \\
\end{array}$ \\
$\begin{array}{l}\text { Post 15: (fit food advertisement) Love Bowl! I love to mix everything that is healthy and } \\
\text { nourish my energy body and soul. (Pugliesi, 2018f, own translation) }\end{array}$ \\
\hline Desire & $\begin{array}{l}\text { Post 8: (resort advertisement) One quarter of that (thought balloon emoji) (Pugliesi, 20181, } \\
\text { own translation) }\end{array}$ \\
\hline \multirow{3}{*}{ Irresistibility } & $\begin{array}{l}\text { Post 20: (fit sweet advertisement) Seriously now: Take the @docemaisfit of coconut kiss and } \\
\text { leave it in the freezer for a few minutes! OMG (eight emojis of passionate faces) (Pugliesi, }\end{array}$ \\
& 2018m, own translation) \\
\hline Happiness & $\begin{array}{l}\text { Post 10: (health sweet popcorn advertisement) Do you Want to make me happy? Give me } \\
\text { some sweet popcorn! I’ve been crazy since I was little! Anyone who has tasted @senho- } \\
\text { rapipoca (this one is with whey cacao I don't have words!) knows what I'm talking about! } \\
\text { (Pugliesi, 2018n, own translation) }\end{array}$ \\
\hline
\end{tabular}

Table 6. Emotions Gabriela Pugliesi expressed about the products

The feelings described by this influencer communicate that she uses the products and not just endorse them. As in the case of Juliana Salimeni, Gabriela shows satisfaction in announcing them, since she appreciates and develops a relationship with the good, service and brand that brings happiness, love, desire and irresistibility to her. By appearing to use the product, the message posted seems to gain more credibility and trust from followers (Lim et al., 2017). By stating that she uses the product, Gabriela gives opportunities for the followers learn about her opinions and life (Vogel et al., 2015), arousing the desire of her audience to consume this product in order to acquire some similarity with the digital fitness influencer, serving as inspiration for them (Meyers, 2017).

Finally, the theme of interaction of the influencer with her followers in the posts was developed from Gabriela's texts. Four types of messages have been identified: motivational Phrases, questions, promotional codes and instructions (See table 7).

In these types of message, Gabriela tried to give as much information as possible about the goods and services endorsed acting well in the role of information intermediary, facilitating their dissemination to her online followers (Uzunoglu \& Kip, 2014). The instructions go beyond the features and benefits of the products, including how to use them, where to get them and where to find more information about it.

The questions posed by Gabriela aim to generate interactions with followers through comments about the product that can express the opinion of the user about it in a spontaneous and natural way (Centeno \& Wang, 2017; Jin \& Phua, 2014). The strategy of promotional codes, in this turn, is an incentive for followers to acquire the advertised good or service with the benefit of discounts granted, it is an advantage perceived by those who follow the influencer's Instagram profile. Finally, the motiva- 


\begin{tabular}{ll}
\hline $\begin{array}{l}\text { Types of } \\
\text { interaction }\end{array}$ & Text \\
\hline \multirow{2}{*}{$\begin{array}{l}\text { Carpe Diem/Determination - Post 1: (Clothing advertisement) "Monday I start" has ar- } \\
\text { rived!! Go! (hand emoji making peace sign) @bodyforsure (Pugliesi, 2018o, own translation) }\end{array}$} \\
Phrases \\
creasingly refines our attunement to the universe. We perceive our insignificance in the face of \\
the greatness of life! (Pugliesi, 2018a, own translation) \\
Spirituality - Post 13: (underwear advertisement) Who ever looked up to heaven and \\
thanked you today? (emoji hands together - praying) (emoji red heart). (Pugliesi, 2018d, own \\
translation)
\end{tabular}

Table 7. Types of interaction - Gabriela Pugliesi

tional phrases reflect Gabriela's own lifestyle, based on the search for a spirituality that connects the human being and nature, which must be lived daily, emphasizing the role of the present in the transformation of the body and the soul. Therefore, elements of determination and linked to the premise of Carpe Diem are witnessed in the phrases posted by the digital influencer. With such phrases, Gabriela reinforces her role as an endorser by provoking and inspiring people, being a reference for them (Meyers, 2017).

\section{Alice Matos}

Alice's posts highlighted her body as a result of an effort that dignifies her, which deserves to be shown and reaffirmed from the endorsed products (See figure 8).

She exposes her defined belly and large bosoms as symbols of success and sensuality through her muscles, because they communicate her determination, her bodily building routine, and her self-love (Powers \& Greenwell, 2016). Her sensuality is en- 
hanced by exposing her breasts as symbols of fertility and femininity, more also freedom, feminism and empowerment. Alice's body represents her trophy, her greatest success. For this reason, the photos in which she stands it out are the most liked by her followers. The post 8 , for example, was the most liked $(146,616)$ and commented $(2,503)$ post among Alice's others analyzed, demonstrating the greater efficiency of endorsement when the digital influencer shows her body advertising the product, recognizing it as a means of spreading a more persuasive and compelling message (Kapitan \& Silvera, 2016).

By the way, she uses clothing that highlight her achievements, modeling her body as a second skin, using them as an extension of the purpose of the activity too (See Figure 8, post 2). From the clothed dresses, Alice externalizes her youth and the acquired body, there is no relation to the natural or innate, everything is reflected in the determination and the daily focus, in vigorous exercises (Albinsson et al., 2017) in favor of the body seen as ideal of her corporal success. Then, the freedom is reflected in the moving body through the exercises done to reach the goals. This determination is also a reflection of the professional success of the digital influencer who is entrepreneurial in the field of women's fitness clothing (See figure 8, post 10).

The influencer's body meanings are extended in the products she advertises in her posts (Belk, 1988, 2014). There is evidence for the care of the corporeal from the use of various products such as dietary supplements and vitamins, fit foods like pasta, chocolate and sweets that allow Alice to eat without feeling guilty (See figure 9, post 14) and the coach and bodybuilding, all goods and services focused on the fitness lifestyle (Crossley, 2005). Thus, there is a search for fashion trends from fairs and events (See figure 9, post 9) and for high-tech products in the construction of muscular and well-dressed body. Finally, this digital

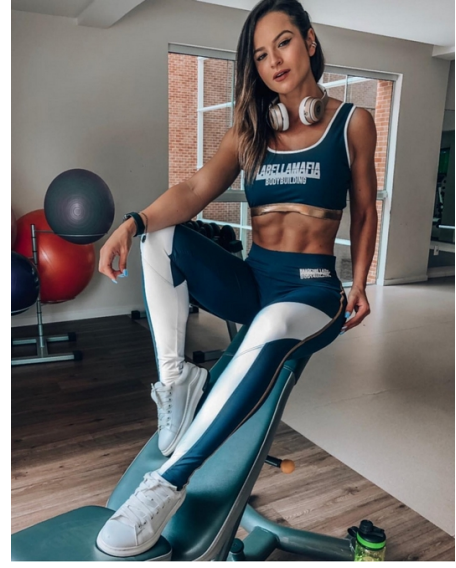

Post $2-04 / 10 / 2018$

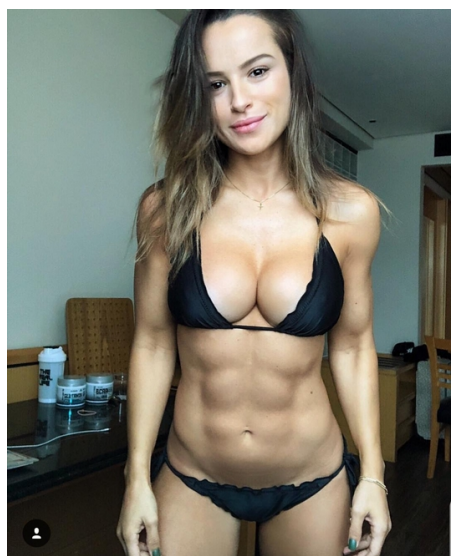

Post $8-22 / 10 / 2018$

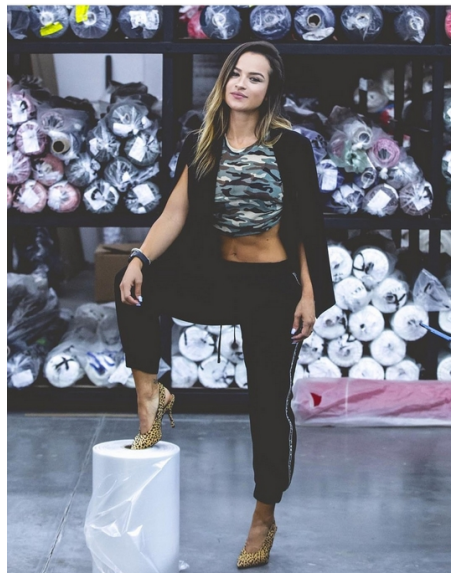

Post $10-26 / 10 / 2018$

* From top to bottom: Clothing advertisement photo; Fit Coach advertisement photo; Clothing and Magazine advertisement photo.

Figure 8. Efforts for the desired body - Alice Matos

Source: Matos (2018a, 2018b, 2018c) 


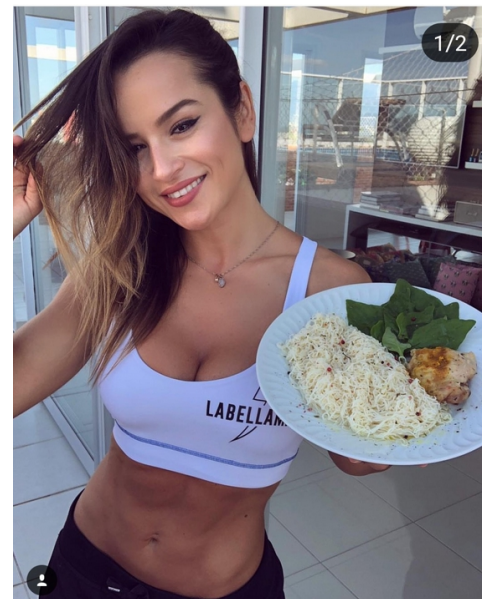

Post $14-30 / 10 / 2018$

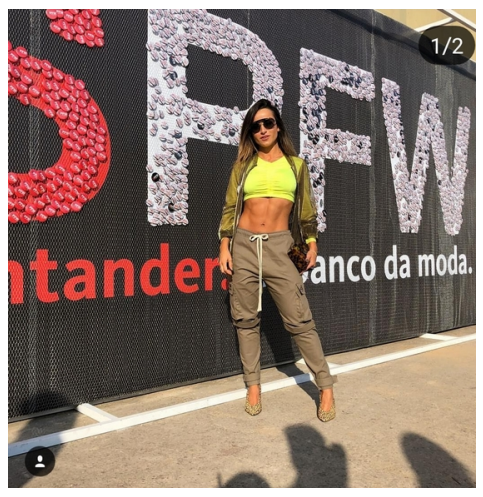

Post $9-23 / 10 / 2018$

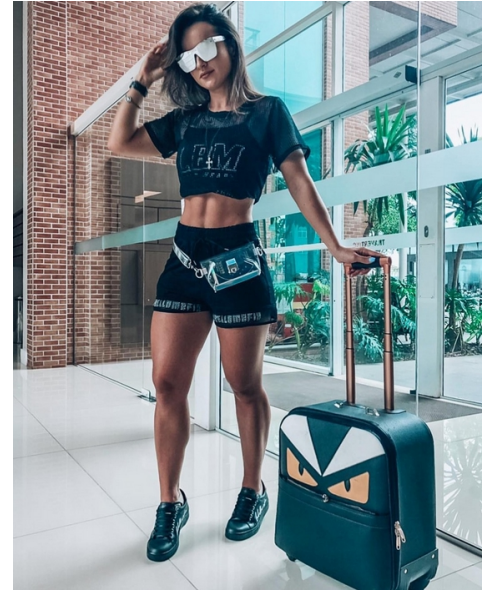

Post $13-29 / 10 / 2018$

* From left to right: Fit pasta advertisement photo; São Paulo Fashion Week advertisement photo; Airline advertisement photo.

Figure 9. Body Extension - Alice Matos

Source: Matos (2018d, 2018e, 2018f)

fitness influencer exposes her freedom and professional success from her trips (See figure 9, post 13).

As with the other two digital influencers analyzed, in Alice's posts it was possible to identify the subjects of body exposure and body extension already described, and the themes of interaction with the product/brand and interaction with followers. In relation to the first it was possible to observe i) the form of exposure of the product, ii) the relation between it and the influencer, and iii) the emotions that she describes when endorsing it. In all posts the influencer appears exposing (See figure 10, post 12) or using the product (See figure 10, posts 1 and 4).

In post 12 in which the influencer exposes the pot of food supplement was the least commented (149) and liked (14.641) by the followers. It seems to be evident from the analyzes that posts in which the digital influencer is placed in the background or when there is something that draws more attention and overshadows the role of the endorser in photography, as the robots in the image, are those that generate the lowest level of integration. Thus, the outstanding role of the digital endorser in photography with the announced product is vital, because this individual is who has gained space and voice through social networks (Booth \& Matic, 2011), wanting to be heard and appreciated by the followers.

It is important to consider that Alice, as well as endorser, also owns one of the brands that she announces and has partnered with at least one of the companies 


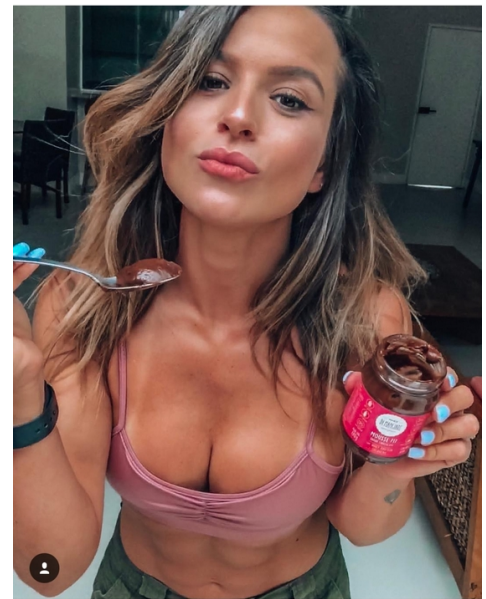

Post $1-02 / 10 / 2018$

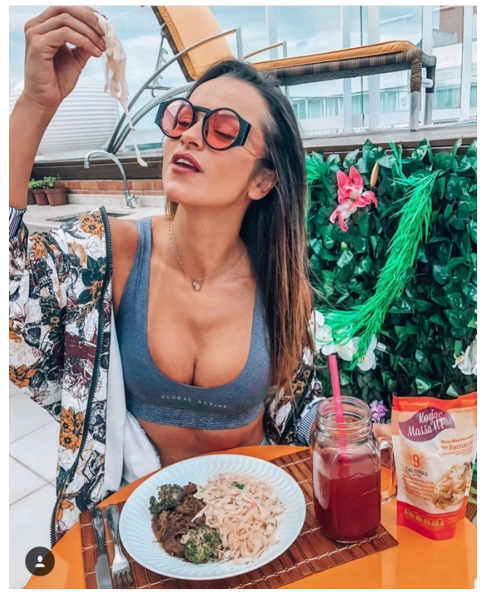

Post $4-10 / 10 / 2018$

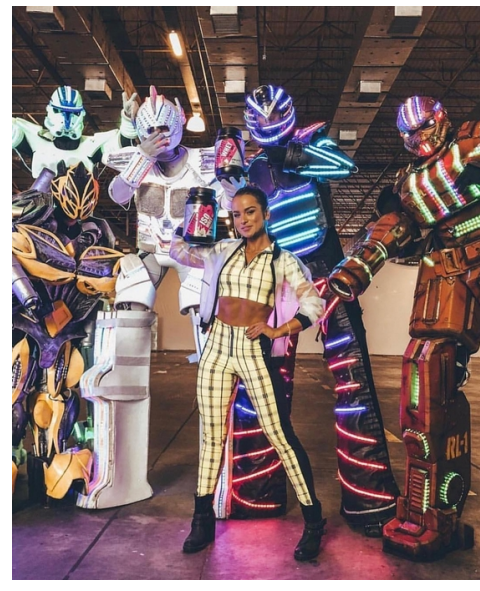

Post $12-29 / 10 / 2018$

* From left to right: Fit Sweet advertisement photo; Fit Pasta advertisement photo; Food Supplements advertisement photo.

Figure 10. Exposure Products - Alice Matos

Source: Matos (2018g, 2018h, 2018i)

whose products communicated by her, demonstrating the multiple roles adopted by this influencer. Lastly, still stand out the feelings to the goods and services announced by Alice (See table 8).

\begin{tabular}{|c|c|}
\hline Emotion & Text \\
\hline \multirow[b]{2}{*}{ Affection/love } & $\begin{array}{l}\text { Post 3: (resort advertisement) [...] I'm in love with this place. @solarmirados \#relax \#pra- } \\
\text { iadorosa \#rosabeach (Matos, 2018j, own translation) }\end{array}$ \\
\hline & $\begin{array}{l}\text { Post 15: (fit sweet advertisement) After lunch, when you want to eat sweet food! These are } \\
\text { my "two loves" (two emoji sweetheart lovers) chocolate and brigadeiro fit (Matos, 2018k, } \\
\text { own translation) }\end{array}$ \\
\hline Desire & $\begin{array}{l}\text { Post 1: (fit sweet advertisement) When you hit that sweet eating desire (chocolate in my } \\
\text { case) it has to be one that's really worth it (Matos, } 2018 \mathrm{~g} \text {, own translation) }\end{array}$ \\
\hline Irresistibility & $\begin{array}{l}\text { Post 5: (fit sweet advertisement) [...] The challenge is to eat a single spoon of it (Matos, 20181, } \\
\text { own translation) }\end{array}$ \\
\hline Happiness & $\begin{array}{l}\text { Post 6: (fitness fair advertisement) I'm excited to go to the first @mrolympiabrazil with @la- } \\
\text { bellamafia during this weekend in São Paulo. (Matos, 2018m) }\end{array}$ \\
\hline
\end{tabular}

Table 8. Emotions Alice Matos expressed about the products

The main sentiments demonstrated in Alice's texts are positively linked to the possibility of enjoying foods developed to serve the fitness lifestyle. Consequently, she demonstrates affection, desire, irresistibility and happiness to products that meet the expectations of a particular mode of feeding, with restrictions that help maintain the muscular body. These same feelings are extended to other services such as fitness resorts and fairs, all of them encouraging people "to evaluate and work on their bodies" (Maguire, 2008, p. 3). 
Finally, the interaction of this influencer with her followers is described. Her texts were intended to generate some kind of interaction, encompassing five types of messages, they are: motivational phrases, questions, discounts, instructions and invitations (See table 9).

\begin{tabular}{|c|c|}
\hline $\begin{array}{l}\text { Types of } \\
\text { interaction }\end{array}$ & Text \\
\hline \multirow{4}{*}{$\begin{array}{l}\text { Motivational } \\
\text { Phrases }\end{array}$} & $\begin{array}{l}\text { Determination }- \text { Post } 4 \text { : (fit pasta advertisement) Your success is found in your daily } \\
\text { routine (Matos, 2018h) }\end{array}$ \\
\hline & $\begin{array}{l}\text { Self-love - Post 14: (fit pasta advertisement) Love yourself enough to live a healthy life- } \\
\text { style. (Matos, 2018d) }\end{array}$ \\
\hline & $\begin{array}{l}\text { Importance of partnerships - collectivity - Post 7: (Fitness fair, choting and fitness } \\
\text { championship advertisement) Alone we go fast. Together we go further. @labellamafia } \\
\text { @nutrata (Matos, 2018n) }\end{array}$ \\
\hline & $\begin{array}{l}\text { Self-esteem - Post 2: (clothing advertisement) build the life (emoji coração azul) you } \\
\text { love (Matos, 2018a) }\end{array}$ \\
\hline Questions & $\begin{array}{l}\text { Post 16: (Airlines advertisement) guess where my next destination will be? (Matos, } \\
\text { 2018o) }\end{array}$ \\
\hline Discounts & $\begin{array}{l}\text { Post 13: (Airlines advertisement) [...] who accompanies me knows that I only travel from } \\
\text { @skymilhas They have discounts of up to } 50 \% \text { (two emojis of frightened cats) in the air } \\
\text { tickets to Brazil and abroad! It's worth it! (Matos, 2018f, own translation) }\end{array}$ \\
\hline \multirow{6}{*}{ Instructions } & $\begin{array}{l}\text { Product features - Post 14: (fit pasta advertisement) [...] And it is made of Glucoman- } \\
\text { nan, the natural fiber of the Konjac root, which increases the sensation of satiety, ex- } \\
\text { panding in the stomach after ingestion (Matos, 2018d, own translation) }\end{array}$ \\
\hline & $\begin{array}{l}\text { Product benefits - Post 15: (fit sweet advertisement) [...] This \#docefit in pot, is won- } \\
\text { derful, satisfies the urge to eat sweet weightless in consciousness! (Matos, 2018k, own } \\
\text { translation) }\end{array}$ \\
\hline & $\begin{array}{l}\text { Where to find the products - Post 10: (magazine advertisement) [...] Story link in sto- } \\
\text { ries. (Matos, 2018c, own translation) }\end{array}$ \\
\hline & $\begin{array}{l}\text { How to use the product - Post } 4 \text { : (pasta fit advertisement) [...] just wash and leave } 2 \\
\text { minutes on the fire. As the taste is neutral I always put coconut oil, salt, pepper and a } \\
\text { protein like beef or chicken. (Matos, 2018h, own translation) }\end{array}$ \\
\hline & $\begin{array}{l}\text { Where to find more information about the product - post } 15 \text { (fit sweet advertise- } \\
\text { ment) [...] check it out on their instagram: @dimangiare (Matos, } 2018 \mathrm{k} \text {, own translation) }\end{array}$ \\
\hline & $\begin{array}{l}\text { Description of the brand history - Post } 6: \text { (clothing advertisement) [...] It's a huge job } \\
\text { to create the concept, set up a stand and take our team and ambassadors from one side of } \\
\text { the world to the other. (Matos, } 2018 \mathrm{~m} \text {, own translation) }\end{array}$ \\
\hline Invitations & $\begin{array}{l}\text { Post 7: (Fitness fair, clothing and fitness championship advertisement) I'll wait for you } \\
\text { today, to check all the news, at the booth \#LABELLAMAFIA 14h I'll be with the athletes } \\
\text { and personality! (emoji showing biceps) (yellow heart) (Matos, 2018n, own translation) }\end{array}$ \\
\hline
\end{tabular}

Table 9. Types of interaction - Alice Matos

Motivational phrases are related to the effort to reach the goals. Therefore, they encourage determination, the search for partnerships, self-love and self-esteem, reverberating the importance of work and dedication, encouraging the body to become the source of concern and dedication of individuals (Maguire, 2002; Powers \& Greenwell, 2016). The questions and invitations made by Alice aim to generate actions, response 
behaviors that help in the dissemination of information and experiences of the followers with the product. These elements create a better flow of information and engagement in the online endorsement strategy made by a digital influencer.

Different from the other influencers analyzed, Alice does not have promotional coupons in her posts, but informs the consumers of discounts that companies make available in the sale of the products. Finally, product orientations are numerous, characterizing this influencer among others as providing more information about endorsed goods and services, such as characteristics, benefits, where to find and use them, where to have more information about it and the history of the brand. It is important to mention that Alice is the only one of the digital fitness influencers analyzed who writes her posts in more than one language (Portuguese, English and Spanish). It achieved that two important elements in the endorsement of products are fulfilled by Alice: this influencer shares more information (Osborne-Gowey, 2014) and the greater reach of the message through the different languages used by her.

\section{What are the key considerations about endorser posts?}

Our findings provide some support for setting some post influencing fitness standards, regardless of the endorsed product. In general, they expose the body and its meanings through flashy photographs and spontaneous texts, transferring such symbolisms to the goods and services announced. In addition, the posts indicate a close relationship between product and influencer, which is not limited to its endorsement, but its use, giving credibility to the message communicated. Through the posts, the digital influencers also seek interaction with their audience, bringing them closer to the message so that they feel active in building opinions about the post and, consequently, about the propagated product. In the mental map (See figure 11), we demonstrate these elements that form the way of products endorsement by digital fitness influencers on Instagram.

Thus, we identify some elements that favor and increase the efficiency of endorsement made by digital influencers. The role of the body in the process of attraction to the message was evidenced, especially by having as subjects of analysis women who adopt a fitness lifestyle. The photographs posted by the influencers that obtained high levels of interaction were those in which their bodies are shown in bikinis, lingerie and tight clothing. These women have millions of followers in their profiles on Ins tagram precisely because of the body they have seen as a source of inspiration for many of their audience. The posts that highlight the corporeal are, therefore, the most liked and commented to people who accompany them virtually, reinforcing the need to care for the body (Maguire, 2002), to strive to transform it (Powers \& Greenwell, 


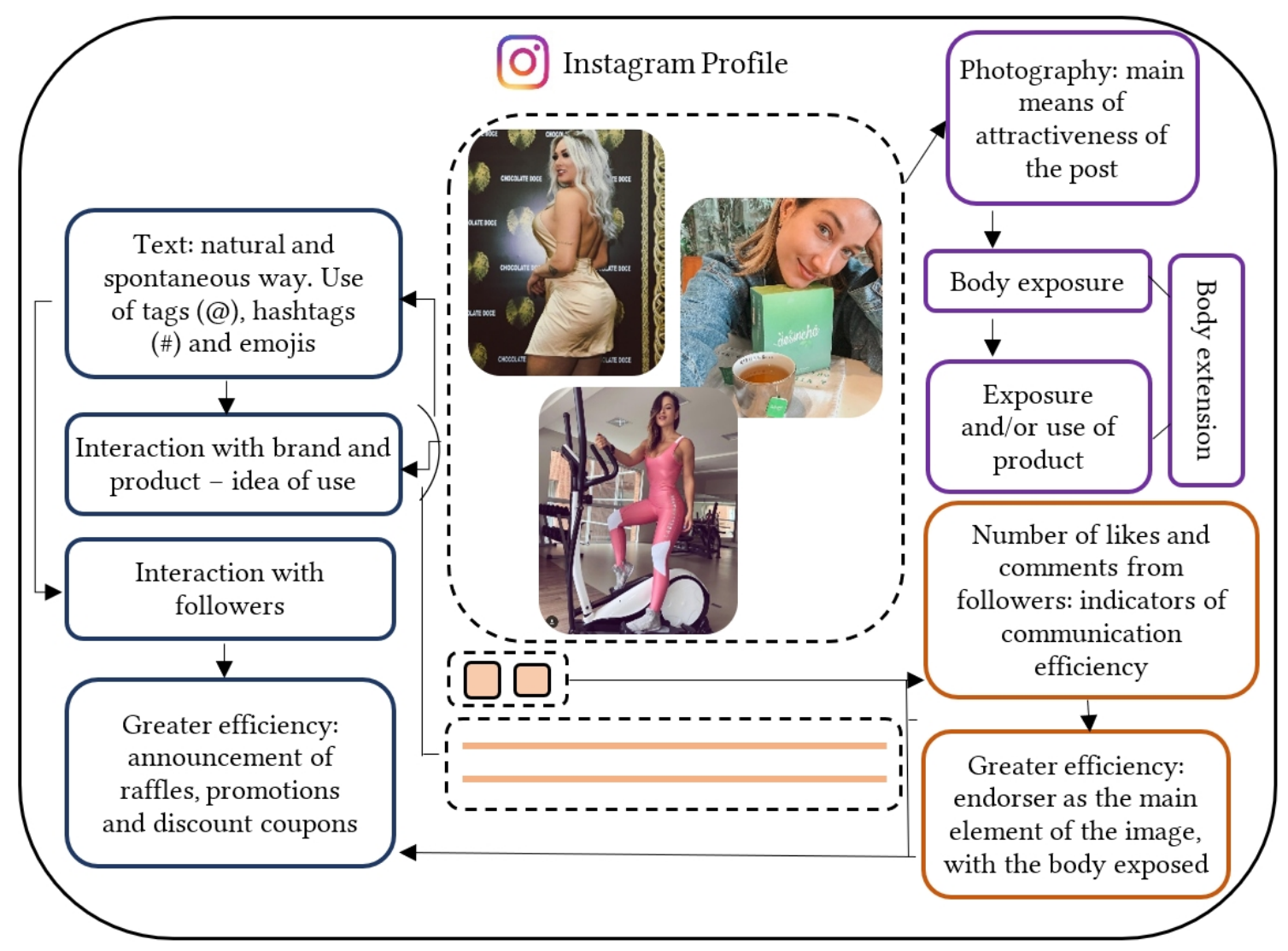

Figure 11. Mental map of posts

2016; Scott et al., 2017), to convey meanings like beauty, health, sensuality and success (Goellner, 2008).

Therefore, exposed in the publications was understoojpdd as the main element of intersubjective communication of the posts, reflecting the internal and external domains of the individual who exposes him, demonstrating the daily co-construction experienced by the body, the need for its shaping and adjustment, pointing out the importance of products endorsed by influencers to achieve, at least momentarily, this feat (Fontanille, 2019). At the same time, this body that mediates sociability in influencers' social networks is the demonstration of intimacy as a spectacle (Sibilia, 2008), justifying to some extent the qualification of fame attributed to the Brazilian fitness muses analyzed (Sibilia, 2010).

The way how the product is endorsed in the postings also impacted the level of interaction. Exposed goods without the presence of the influencer or exposed in photographs where the endorser is not prominent are not as effective as the postings that bring the digital influencer on leading role by exposing and/or using the product, confirming the premise that the digital endorser, specially her/him body, acts as an avatar 
of brand value (Powers \& Greenwell, 2016). The greater interaction in posts where the image of the photograph is the influencer also reinforces the idea that such an online celebrity is seen as a reference for the audience capable of modifying daily living patterns and generating social differentiation that is sought by the public, in order to expand the behavior of individuals, including consumption (Castells, 2011).

In addition, many of the texts in the posts of the influencers brought some emotional element of the endorser about the announced good or service, besides the tips of how to use it, to acquire it and the benefits generated by its use. Such a strategy can help the communicated message to be viewed with greater confidence by the followers (Lim et al., 2017), because describing feelings such as love, happiness, desire and dependence on products, and offering some descriptions of their experiences, endorsers convey the idea that they actually use them.

It is also important to consider some ways to generate interaction with followers from the posts made. All digital fitness influencers sought to use messages that led to some kind of interaction with the audience, making the post more attractive, receiving almost immediate response times (Power, 2014) of the audience. Questions, motivational phrases, product instructions, invitations, and promotional coupons and sweepstakes were the strategies used. The latter, in particular, had great acceptance and interaction of the influencers for the benefits generated, such as discounts and gifts.

\section{Conclusions}

This investigation of the endorsement phenomenon carried out by digital fitness influencers corroborated to the understanding of the aspects that make up this promotion strategy, identifying certain patterns, certain categories contained in the postings. From this analysis, we were able to identify some issues that generate greater communicative efficiency of the endorsement in the digital profile of influencers.

Among these issues, we perceive the importance of the corporeal in the process of advertisement attractiveness and the central role to be played by the endorser in the generation of online interactivity, trust in the product and desire to have it. Such influencers are more than endorsers, they are avatars of the brand they advertise, once they use their virtual spaces to communicate it (Sibilia, 2008), make it known and familiar to the millions of followers who accompany daily the exposed life of these influencers. The more intimate the post, the greater its attractiveness, reinforcing the spectacle of the self-shown on social networks (Sibilia, 2008). The efficiency of posting 
is therefore determined by excess, by wide-open and, at the same time, mysterious exposure (Han, 2012/2018).

We also identified that in this endorsement process an intense link between influencers and brands is created that implies the extension of the meanings of the individual's bodies, the lifestyle propagated by them in social networks and shared values and beliefs in their online profiles for the goods and services they exposed. Furthermore, in addition to the body as a commodity (Han, 2012/2018), spectra of the lives of these influencers also become a commodity. Such merchandise already purchased by organizations must be displayed and ready to be consumed free of charge by followers in order to shape living standards, behavior, perceptions and values.

We concluded that the closer the endorsement reflects the endorsers and their characteristics, the better the acceptability and the communicative efficiency of it. Thus, the product must emerge as an extension of the influencers, as a means of constructing their images, making this endorsement strategy understood by the followers as demonstrations of the endorsers' usual consumer practices. In this triad (brand/ product - digital influencer digital - follower), the likes and comments of followers are the thermometers for gauging the relationship built and maintained from the online interaction.

Therefore, we understand the need for future studies that analyze followers' comments in the posts of digital influencers. Such texts can contribute to a holistic view of the online triad, bringing clarification about the role of followers in the product advertising process in profiles on Instagram.

\section{Acknowledgements}

This work was supported by the National Council for Scientific and Technological Development (CNPq) under Grant number [140806/2019-9] and the National Council for the Improvement of Higher Education (CAPES) under Grant number [88881.187310/2018-01].x

\section{References}

Albinsson, Pia A.; Perera, P. Yasanthi \& Shows, G. David. (2017). Pursuing fitness: how dialectic goal striving and intersubjectivity influence consumer outcomes. Consumption Markets \& Culture, 20(1), 35-58. https://doi.org/10.1080/10253866.2016.1172213 
Almeida, Marcos I. S.; Coelho, Ricardo L. F.; Camilo-Junior, Celso G. \& Godoy, Rafaella M. F. (2018). Who Leads Your Opinion? Opinion Leaders' Influence on Virtual Engagement. RAC-Revista de Administração Contemporânea, 22(1), 115-137. https://doi.org/10.1590/1982-7849rac2018170028

Araujo, Theo; Neijens, Peter \& Vliegenthart, Rens. (2016). Getting the word out on Twitter: the role of influentials, information brokers and strong ties in building word-of-mouth for brands. International fournal of Advertising, 36(3), 496-513. https://doi.org/10.1080/02650487.2016.1173765

Belinska, Solvita. (2018). Representation of Woman's Body on Instagram: Qualitative Content Analysis of the year 2018 posts of top fitness influencer Michelle Lewin. Unpublished doctoral disertation, University School of Humanities.

Belk, Russell W. (1988). Possessions and the Extended Self. fournal of Consumer Research, 15, 139-168. https://doi.org/10.1086/209154

Belk, Russell W. (2014). Digital consumption and the extended self. Fournal of Marketing Management, 30(1/2), https://doi.org/10.1080/0267257X.2014.939217

Bisma, Nasir; Abbas, Tanveer; Abrar, Muhammad \& Iqbal, Asif. (2017). Impact of television advertisement on unhealthy weight control behaviors and eating disorders: Mediating role of body image. Pakistan Administrative Review, 1(1), 42-60.

Booth, Norman \& Matic, Julie Ann. (2011). Mapping and leveraging influencers in social media to shape corporate brand perceptions. Corporate Communications: An International fournal, 16(3), 184-191. https://doi.org/10.1108/13563281111156853

Castells, Manuel. (2011). The rise of the network society: The information age: Economy, society, and culture (Vol. 1). Wiley-Blackwell.

Centeno, Dave \& Wang, Jeff J. (2017). Celebrities as human brands: An inquiry on stakeholder-actor co-creation of brand identities. Fournal of Business Research, 74, 133-138. https://doi.org/10.1016/j.jbusres.2016.10.024

Crossley, Nick. (2005). Mapping Reflexive Body Techniques: On Body Modification and Maintenace. Body \& Society, 11(1), 1-35. https://doi.org/10.1177/1357034x05049848

Fontanille, Jacques. (2019). As vias (e as vozes) do afeto. Galáxia, 137-162. https://doi.org/10.1590/1982-25532019545632

Fuchs, Christian. (2014/2017). Social Media: A Critical Introduction. Sage.

Godey, Bruno; Manthiou, Aikaterini; Pederzoli, Daniele; Rokka, Joonas; Aiello, Gaetano; Donvito, Raffaele \& Singh, Rahul. (2016). Social media marketing efforts of luxury brands: Influence on brand equity and consumer behavior. Journal of Business Research, 69(12), 5833-5841. https://doi.org/10.1016/j.jbusres.2016.04.181

Goellner, Silvana V. (2008). Deporte y Cultura Fitness: La Generización de Los Cuerpos Contemporáneos. Revista Digital Universitaria, 9(7), 3-11.

Han, Byung-Chul. (2012/2018). La agonia del Eros. Herder Editorial. 
Hanna, Richard; Rohm, Andrew \& Crittenden, Victoria L. (2011). We're all connected: The power of the social media ecosystem. Business Horizons, 54, 265-273. https://doi.org/10.1016/j.bushor.2011.01.007

Holt, Douglas. (2016). Branding in the Age of Social Media. Harvard Business Review,41-50.

IHRSA, International Health, Racquet \& Sportsclub Association. (2017, agosto). Relatório Global IHRSA 201 mil academias 83,1 bilhões de dólares 162 milhões de clientes Fitness cresce no mundo e Brasil ainda sofre com a crise econômica. Revista ACAD Brasil, pp. 10-21.

Jin, Seung-A. A. \& Phua, Joe. (2014). Following Celebrities' Tweets About Brands: The Impact of Twitter-Based Electronic Word-of-Mouth on Consumers' Source Credibility Perception, Buying Intention, and Social Identification with Celebrities. Fournal of Advertising, 43(2), 181-195. https://doi.org/10.1080/00913367.2013.827606

Kapitan, Sommer \& Silvera, David H. (2016). From digital media influencers to celebrity endorsers: attributions drive endorser effectiveness. Marketing Letters, 27, 553-567. https://doi.org/10.1007/s11002-015-9363-0

Kuchler, Hannah. (2017) Instagram Adds 100m Users in 4 Months [online]. Financial Times. www.ft.com/content/d14bab90-29fd-11e7-bc4b-5528796fe35c.

Lim, Xin J.; Radzol, Aifa F.; Cheah, Jun-Hwa \& Wong, Mun W. (2017). The Impact of Social Media Influencers on Purchase Intention and the Mediation Effect of Customer Attitude. Asian fournal of Business Research, 7(2), 19-36. https://doi.org/10.14707/ajbr.170035

Liu, Brooke F.; Jin, Yan; Briones, Rowena \& Kuch, Beth. (2012). Managing turbulence in the blogosphere: Evaluating the blog-mediated crisis communication model with the American red-cross. Fournal of Public Relations Research, 24(4), 353370. https://doi.org/10.1080/1062726x.2012.689901

Maguire, Jennifer S. (2002). Body Lessons: Fitness Publishing and the Cultural Production of the Fitness Consumer. International Review For The Sociology Of Sport, 37(3-4), 449-464. https://doi.org/10.1177/1012690202037004896

Maguire, Jennifer S. (2008). Fit for Consumption: Sociology and the business of fitness. Routledge.

Mangold, W. Glynn \& Faulds, David J. (2009). Social media: the new hybrid element of the promotion mix. Business Horizons, 52(4), 357-365. https://doi.org/10.1016/j.bushor.2009.03.002

Matos, Alice. [@alice]. (n.d.). Posts [Instagram Profile] Retrieved December 28, 2018 from https://www.instagram.com/alice/?hl=pt-br.

Matos, Alice. [@alice]. (2018a, October 4). build the life (emoji coração azul) you love. Outfit: @labellamafia FREE SHIPPING WORLDWIDE (emoji avião) (emoji caixa de papelão) [Photograph and text]. Instagram. https://www.instagram.com/p/ BohSOIGg5_1/?igshid=m2ozdmy53yrl

Matos, Alice. [@alice]. (2018b, October 22). It's Monday and it's time to go \#beastmode (emoji carinha debochada). Powerade by @coachbueno [Photograph]. 
Instagram. https://www.instagram.com/p/BpPfNyGA_Ts/? igshid=pum2r9358qm5

Matos, Alice. [@alice]. (2018c, October 26). Success is a decision. GIRL BOSS FOR REAL \#labellamafia \#factory \#brazil. Tem entrevista pra @RevistaVersar Santa Catarina aqui na fábrica da @Labellamafia [Photograph]. Instagram. https://www.instagram.com/p/BpaLEwNghMO/?igshid=4c7komwjm9tz

Matos, Alice. [@alice]. (2018d, October 30). Love yourself enough to live a healthy lifestyle. Emagrecer sem passar fome comendo massa parece surreal né! \#soquenao rsrs As massas @konjacmassa [Photograph and text]. Instagram. https://www.instagram.com/alice/?hl=pt-br.

Matos, Alice. [@alice]. (2018e, October 23). After a true fitness weekend, it's time for a spin at São Paulo Fashion Week (emoji carinha com óculos escuros).

[Photograph]. Instagram. https://www.instagram.com/p/BpSDyEdgOVk/? igshid=18nld0gibh9fm

Matos, Alice. [@alice]. (2018f, October 29). New Monday, new week, new goals (emoji de coração preto). Desejando esse bronze e embarcar pra a próxima trip [Photograph and text]. Instagram.

https://www.instagram.com/p/Bph5ta1gwZJ/?igshid=13zplqji1quxi

Matos, Alice. [@alice]. (2018g, October 02). life is sweet (emoji do coração rosa em vários em tons de rosa) Happy Tuesday! Quando bate aquela vontade de comer doce [Photograph and text]. Instagram. https://www.instagram.com/alice/? $\mathrm{hl}=\mathrm{pt}-\mathrm{br} . \mathrm{nd}$

Matos, Alice. [@alice]. (2018h, October 10). Your success is found in your daily routine. @konjacmassa_mf \#konjacmassamf \#lowcarb \#glutenfree \#massafitness \#functionalfood \#healthyfood [Photograph and text]. Instagram. https://www.instagram.com/p/BowWaebggdP/?igshid=zl3yezdxnot5

Matos, Alice. [@alice]. (2018i, October 29). Hello Monday, let's do this! At the last expo in great company... With my \#wheyproteinisolated @nutrata \& @labellamafia [Photograph]. Instagram. https://www.instagram.com/p/BphPSNCg_qA/? igshid=19q22t4e937bi

Matos, Alice. [@alice]. (2018j, October 6). A cloudy day in paradise. What are you doing on Saturday? Dia nublado por aqui... Oq vocês estão fazendo nesse sábado! [Text]. Instagram. https://www.instagram.com/p/BomtE3jgx-C/? igshid=7zr9xm8vrv15

Matos, Alice. [@alice]. (2018k, October 31). Pra depois do almoço qndo bate a vontade de comer doce! Esses são o meu "dois amores" (dois emojis carinhas apaixonadas) [Text]. Instagram. https://www.instagram.com/p/Bpmbf3wgnCn/? igshid $=1 \mathrm{u} 8 \mathrm{iqkxbss} 5 \mathrm{~s} 4$

Matos, Alice. [@alice]. (2018l, October 16). Fall in love with take care of yourself (emoji com coração azul) Um vício chamado chocolate [Text]. Instagram. https://www.instagram.com/alice/?hl=pt-br.

Matos, Alice. [@alice]. (2018m, October 17). I'm excited to go to the first @mrolympiabrazil with @labellamafia during this weekend in São Paulo. 
[Text]. Instagram. https://www.instagram.com/p/BpCXD_UghuA/? igshid $=4 \mathrm{rhkn} 1 \mathrm{~h} 3 \mathrm{y} 79 \mathrm{w}$

Matos, Alice. [@alice]. (2018n, October 20). The future of fitness is now! Empolgada pra o segundo dia da expo. Lá no stories dá pra acompanhar o [Text]. Instagram. https://www.instagram.com/p/BpKWk8TAl_m/?igshid=1spgv80f0h2v4

Matos, Alice. [@alice]. (2018o, October 31). guess where my next destination will be? The trip is in a week. (emoji de avião decolando) (frase anterior traduzida para português) [Text]. Instagram. https://www.instagram.com/p/BpnDRxTAakK/? igshid=c9w56kzvh4aa

Meikle, Graham. (2016). Social Media: Communication, Sharing and Visibility. Routledge.

Meyers, Cynthia B. (2017). Social Media Influencers: A Lesson Plan for Teaching Digital Advertising Media Literacy. Advertising \& Society Quarterly, 18(2), 131. https://doi.org/10.1353/asr.2017.0018

Momany, Muaid \& Alshboul, Abdullah. (2016). Social media marketing: utilizing social media to advance brand awareness and increase online sales. International Journal of Business, Marketing, and Decision Sciences, 9(1), 33-54.

Osborne-Gowey, Jeremiah. (2014). What Is Social Media? Fisheries, 39(2), 55. https://doi.org/10.1080/03632415.2014.876883

Penn, Gemma. (2000). Semiotic analysis of still images. In Martin W. Bauer \& George Gaskell (Eds.), Qualitative researching with text, image, and sound: A practical handbook (Chapter 13). Sage. https://doi.org/10.4135/9781849209731.n13

Power, Alison. (2014). What is social media? British fournal of Midwifery, 22(12), 896897. https://doi.org/10.12968/bjom.2014.22.12.896

Powers, Devon \& Greenwell, DM. (2016). Branded fitness: Exercise and promotional culture. Journal of Consumer Culture, 17(3), 523-541. https://doi.org/10.1177/1469540515623606

Pugliesi, Gabriela [@gabrielapugliesi]. (n.d.). Posts [Instagram Profile] Retrieved December 28, 2018 from https://www.instagram.com/gabrielapugliesi/

Pugliesi, Gabriela [@gabrielapugliesi]. (2018a October 8). O silêncio e o contato com a natureza afinam cada vez mais nossa sintonia com o universo. [Photograph and text]. Instagram. https://www.instagram.com/p/Boq-gvdgqG6/? igshid=17lh9d93rdp2m

Pugliesi, Gabriela [@gabrielapugliesi]. (2018b, October 1). Nós somos a natureza, e não parte dela (emoji de plantinha na terra) \#Conexão. @galeriatricot [Photograph]. Instagram. https://www.instagram.com/p/BoZitfKgeVR/? igshid=sat2j1u04bam

Pugliesi, Gabriela [@gabrielapugliesi]. (2018c, October 17). Bom dia v(emoji da planta na terra)da! @galeriatricot [Photograph]. Instagram. https://www.instagram.com/p/BpB37KBAmvt/?igshid=k8t8zh435u1h

Pugliesi, Gabriela [@gabrielapugliesi]. (2018d, October 19). Quem aí já olhou pro céu e agradeceu hoje? (emoji mãos juntas - orando) (emoji coração vermelho) @valisere (emoji flor rosa) [Photograph and text]. Instagram. https://www.instagram.com/p/BpHwuz2gE_p/?igshid=irdupdoacc3w 
Pugliesi, Gabriela [@gabrielapugliesi]. (2018e, October 10). Hello Paradise (emoji de coqueiro) @oneandonlypalmilla. (emoji de biquíni roxo)@hypebeachwear \#OneAndOnlyAroundBrazil [Photograph]. Instagram.

https://www.instagram.com/p/Bow7B86gSXZ/?igshid=12lo4y1x5dsl7

Pugliesi, Gabriela [@gabrielapugliesi]. (2018f, October 10) Bowl do amor! Amo misturar tudo q é saudável e nutrir meu corpo e alma de energia. [Photograph and text]. Instagram. https://www.instagram.com/p/BpNAWnBg7nc/? igshid=tqit5tvuckv9

Pugliesi, Gabriela [@gabrielapugliesi]. (2018g, October 29) Vinyasa pra começar a semana (emoji mão unidas - orando) (emoji "terço" indiano vermelho) @bodyforsure \#pugli33 \#yoga \#vinyasa [Photograph]. Instagram. https://www.instagram.com/p/BphsnGtlXc6/?igshid=16mn2lobefrs7

Pugliesi, Gabriela [@gabrielapugliesi]. (2018h, October 24) Boom diaaa!! Café com leite é aquela bebidinha gostosa, confortável, nostálgica (pelo menos pra mim) $e$ energética! [Photograph and text]. Instagram.

https://www.instagram.com/p/BpUAncRgeye/?igshid=123ut5enz0qrm

Pugliesi, Gabriela [@gabrielapugliesi]. (2018i, October 15) (emoji feliz com mãos acenando). @hypebeachwear [Photograph]. Instagram. https://www.instagram.com/p/Bo9rhKhgpWU/?igshid=14le1ta7kgfg6

Pugliesi, Gabriela [@gabrielapugliesi]. (2018j, October 20). O dia já começou maravilhoso! O treino perfeito! Energia perfeita! Tks @studio.kore! [Photograph]. Instagram. https://www.instagram.com/p/BpKPfEDAxRf/? igshid=166jxrpq6s6qg

Pugliesi, Gabriela [@gabrielapugliesi]. (2018k, October 18). Qdo @bodyforsure é look de gym e look do dia tbm! Amo mto! A loja tá incrível [Text]. Instagram. https://www.instagram.com/p/BpFPoEOAZPQ/?igshid=o74uf7lfkrhq

Pugliesi, Gabriela [@gabrielapugliesi]. (20181, October 11). Um quarto desse (emoji de balão de pensamento)@oneandonlypalmilla \#Mexico \#LosCabos \#OneAndOnlyAroundBrazil [Text]. Instagram. https://www.instagram.com/p/ Bozfxbigigk/?igshid=2oa3cs10gy1u

Pugliesi, Gabriela [@gabrielapugliesi]. (2018m, October 27). Agora sério: Pega o @docemaisfit de beijinho de coco e deixa no freezer por uns minutos! PQP (oito emojis carinhas apaixonadas) [Text]. Instagram.

https://www.instagram.com/p/BpcoL9ABYXv/?igshid=re56mq2rzjmw

Pugliesi, Gabriela [@gabrielapugliesi]. (2018n, October 16). Impossivel sobrar alguma (emoji assustado - o grito)! Quer me deixar feliz? Me dá pipoca doce! Eu sou enlouquecida, desde pequena [Text]. Instagram. https://www.instagram.com/p/ Bo-ZJjCgJO9/?igshid=a64omaltyx5o

Pugliesi, Gabriela [@gabrielapugliesi]. (2018o, October 1). "Segunda eu começo" chegou!! Bora (emoji de mão fazendo sinal de paz) @bodyforsure [Text]. Instagram. https://www.instagram.com/p/BoY5Dv7gsdw/? igshid=ijrdwr78ho9n

Pugliesi, Gabriela [@gabrielapugliesi]. (2018p, October 5). fá provaram a balinha sem açúcar sabor açaí da @finibrasil?! Agora n sei qual eu gosto mais [Text]. 
Instagram. https://www.instagram.com/p/BokDJx_g_t6/? igshid $=47 \mathrm{dy} 5 \mathrm{xyq} 4 \mathrm{o} 7 \mathrm{l}$

Pugliesi, Gabriela [@gabrielapugliesi]. (2018q, October 5). Uma das melhores coisas já inventadas: @singubr (emoji de mão com unhas sendo pintadas)! [Text].

Instagram. https://www.instagram.com/p/BohyHT_gAAj/? igshid=1uw1ao3q55yo2

Pugliesi, Gabriela [@gabrielapugliesi]. (2018r, October 22). Agora levo a caixa comigo pq onde eu vou todo mundo quer provaro @desincha (emoji com xícara de chá) [Text]. Instagram. https://www.instagram.com/p/BpPR3mhAl4C/? igshid=1q5310292w63b

Pugliesi, Gabriela [@gabrielapugliesi]. (2018s, October 31). Bem hidratadinhas tomando @fivediamondsoficial todos os dias (emoji metade de um coco)! É água de coco em pó. [Text]. Instagram.

https://www.instagram.com/p/BpmZqAPlC8d/?igshid=18v5sljan62wj

Roth, Anna \& Zawadzki, Tomasz. (2018). Instagram as a tool for promoting superfood products. Annals of Marketing Management \& Economics - International Fournal, 4(1), 101-114. https://doi.org/10.22630/AMME.2018.4.1.8

Salimeni, Juliana. [@jujusalimeni]. (n.d.). Posts [Instagram Profile] Retrieved December 28, 2018 from https://www.instagram.com/jujusalimeni/?hl=pt-br.

Salimeni, Juliana. [@jujusalimeni]. (2018a, October 2). E o tanto que esse conjuntinho da @chocolatedoceoficial é fofo meninas? Biker shorts é tendência e supervaloriza o corpo!! [Photograph and text]. Instagram.

https://www.instagram.com/p/BoaKgOmA8Dn/?igshid=qc80ep3yq1hu

Salimeni, Juliana. [@jujusalimeni]. (2018b, October 5). Sextou né mores?? Bora colocar aquele som e entrar na vibe!! @newmillensuplementos. [Photograph]. Instagram. https://www.instagram.com/jujusalimeni/?hl=pt-br .

Salimeni, Juliana. [@jujusalimeni]. (2018c, October 13). Começa amanhã a maior feira fitness do Brasil, a @brtradingfitness!! Eu vou estar lá no stand da @chocolatedoceoficial [Photograph and text]. Instagram.

https://www.instagram.com/p/BpF-uLqFJOC/?igshid=1qp4dh3iuf64q

Salimeni, Juliana. [@jujusalimeni]. (2018d, October 16). Olha isso mulherada!! Que perfeição são os Apliques de luxo da @todalindamegahairoficial !! Eu amo pq são super práticos [Photograph and text]. Instagram. https://www.instagram.com/jujusalimeni/?hl=pt-br.

Salimeni, Juliana. [@jujusalimeni]. (2018e, October 13). Essa semana teve inauguração do novo espaço@primeivlna minha @clinicasalimeni !! Toda a linha funcional de café, chocolate e capuccino zero açúcar [Photograph and text]. Instagram. https://www.instagram.com/jujusalimeni/?hl=pt-br.

Salimeni, Juliana. [@jujusalimeni]. (2018f, October 26). O bonito é te ver lutar, Acreditar, Nada abala um coração corajoso. O bonito é te ver resistir.Te ver [Photograph and text]. Instagram.

https://www.instagram.com/p/BpZupPnl6lp/?igshid=kxu6cjfy9wtk 
Salimeni, Juliana. [@jujusalimeni]. (2018g, October 11). SORTEIO REALIZADO!!

[Photograph and text]. Instagram. https://www.instagram.com/jujusalimeni/? $\mathrm{hl}=\mathrm{pt}-\mathrm{br}$.

Salimeni, Juliana. [@jujusalimeni]. (2018h, October 30). Eu sou suspeita pra falar pq simplesmente amo minha coleção de tênis @hardcorefootwear!! Me fala se não é um [Photograph and text]. Instagram.

https://www.instagram.com/p/BpjsAJhl2NA/?igshid=1iwkdxk1oeayu

Salimeni, Juliana. [@jujusalimeni]. (2018i, October 31). Nossos olhares são capazes de causar um incêndio onde tudo era faísca (emoji do céu escuro com três estrelas) (óculos deuso [Photograph]. Instagram. https://www.instagram.com/p/BpkQhNlklN/?igshid=12efafekkgdvm

Salimeni, Juliana. [@jujusalimeni]. (2018j, October 22). O q foi esse vestido da @chocolatedoceoficial que usei ontem no último dia da nossa feira @brtradingfitness ?? Eu simplesmente [Text]. Instagram. https://www.instagram.com/jujusalimeni/?hl=pt-br.

Salimeni, Juliana. [@jujusalimeni]. (2018k, October 18). Olhe pro seu amor como eu olho pra minha @mandubim com mel. As pastas @mandubim são as mais deliciosas do. [Text]. Instagram. https://www.instagram.com/jujusalimeni/? $\mathrm{hl}=\mathrm{pt}-\mathrm{br}$.

Salimeni, Juliana. [@jujusalimeni]. (20181, October 4). Hoje é dia de \#tbt, então eu escolhi esse q é recente mas já deu pra sentir saudade!!. [Text]. Instagram. https://www.instagram.com/jujusalimeni/?hl=pt-br.

Salimeni, Juliana. [@jujusalimeni]. (2018m, October 20). Primeiro dia da nossa @brtradingfitness!! Temos muito orgulho de sermos embaixadores dessa feira que já se tornou referência no [Text]. Instagram. https://www.instagram.com/jujusalimeni/?hl=pt-br.

Salimeni, Juliana. [@jujusalimeni]. (2018n, October 1). Sensualizany com a cinta modeladorada @sitelojamodafashion!! Sou totalmente a favor de tudo q pode ajudar a gente se. [Text]. Instagram.

https://www.instagram.com/jujusalimeni/?hl=pt-br.

Salimeni, Juliana. [@jujusalimeni]. (2018o, October 5). É mais fôlego pro seu treino que vc precisa?? Então vc tem que experimentar o PEAK 02 da @oficialfarma !! [Text]. Instagram. https://www.instagram.com/jujusalimeni/?hl=pt-br.

Salimeni, Juliana. [@jujusalimeni]. (2018p, October 25). Você já ouviu falar do Morosil da @oficialfarma ?? Esse produto já é o queridinho de atletas e da galera [Text]. Instagram. https://www.instagram.com/jujusalimeni/?hl=pt-br.

Scott, Rebecca; Cayla, Julien \& Cova, Bernard. (2017). Selling Pain to the Saturated Self. Fournal of Consumer Research, 44(1), 22-43. https://doi.org/10.1093/jcr/ucw071

Sibilia, Paula. (2008). O show do eu: a intimidade como espetáculo. Nova Fronteira.

Sibilia, Paula. (2010). Celebridade para todos: um antídoto contra a solidão? Ciência e Cultura, 62(2), 52-55. http://cienciaecultura.bvs.br/scielo.php?

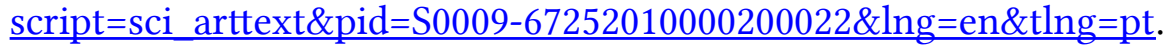


